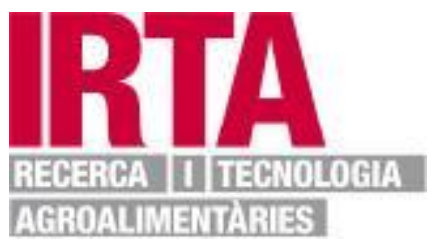

This document is a postprint version of an article published in Meat Science, copyright $\odot$ Elsevier B.V. after peer review.

To access the final edited and published work see:

DOI: 10.1016/i.meatsci.2014.06.031 


\title{
Active and Intelligent Packaging Systems for a Modern Society
}

Carolina E. Realini, Begonya Marcos*

IRTA. Monells, Finca Camps i Armet E-17121. Food Technology Department. Monells (Girona), Spain

*Corresponding author at: IRTA. Monells, Finca Camps i Armet E-17121. Food Technology Department. Monells (Girona), Spain. Tel: + 349726300 52. Fax: + 349726309 80. E-mail: begonya.marcos@irta.es

\begin{abstract}
Active and intelligent packaging systems are continuously evolving in response to growing challenges from a modern society. This article reviews: (1) the different categories of active and intelligent packaging concepts and currently available commercial applications, (2) latest packaging research trends and innovations, and (3) the growth perspectives of the active and intelligent packaging market. Active packaging aiming at extending shelf life or improving safety while maintaining quality is progressing towards the incorporation of natural active agents into more sustainable packaging materials. Intelligent packaging systems which monitor the condition of the packed food or its environment are progressing towards more costeffective, convenient and integrated systems to provide innovative packaging solutions. Market growth is expected for active packaging with leading shares for moisture absorbers, oxygen scavengers, microwave susceptors and antimicrobial packaging. The market for intelligent packaging is also promising with strong gains for time-temperature indicator labels and advancements in the integration of intelligent concepts into packaging materials.
\end{abstract}

Keywords: active, intelligent, packaging, shelf life, muscle foods

\section{Introduction}

Food packaging technology is continuously evolving in response to growing challenges from a modern society. Major current and future challenges to fast-moving consumer goods packaging include legislation, global markets, longer shelf life, convenience, safer and healthier food, environmental concerns, authenticity, and food waste (Kerry, 2014). Every year a growing amount of edible food is lost along the entire food supply chain. Annual food waste generation estimates in Europe are around 89 million tonnes varying considerably between individual countries and the various sectors (European Commission, 2012a). Spoilage of raw meat along the food supply chain (production, retailers, consumers) represents a loss which could be as high as $40 \%$ (Sperber, 2010). Packaging optimisation strategies such as varying pack sizes to help consumers buy the right amount, and designing packaging to maintain food quality and increase its shelf life have been proposed to reduce food waste (European Commission, 2012a).

Food safety is a global priority and one of the major objectives of the current food legislation. However, microbiological risks of food products are even today are one of the main sources of foodborne illnesses. Listeriosis constitutes the highest EU foodborne illness showing a high mortality rate around $13 \%$. The fact that Listeria monocytogenes can grow at refrigeration temperatures $(2-4 \mathrm{O} C)$, makes the occurrence of this pathogen in ready-to-eat (RTE) foods with a relatively long shelf-life, such as fishery products, heat-treated meat products and RTE cheese, of particular concern. In addition, the growing consumer demand for minimally processed, more natural, fresh and convenient food products as well as continuous changes at industrial, retail and distribution levels associated with globalisation pose major 
challenges to food safety and quality. This background offers a unique opportunity to the packaging industry to offer innovative solutions to address the changing demands of the food industry and consumers as well as the increasing regulatory and legal requirements.

The function of food packaging has evolved from simple preservation methods to include such aspects as convenience, point of purchase marketing, material reduction, safety, tamperproofing, and environmental issues (Han, 2014). Active packaging of food is a good example of an innovation that goes beyond the traditional functions of the package in which the package, the product and its environment interact to extend the shelf life of food or to improve its safety or sensory properties, while maintaining the quality of the packed food (Ahvenainen, 2003). Intelligent packaging provides information to the processor, retailer and/or consumer of the status of the food or its surrounding environment (Kerry, O'Grady, \& Hogan, 2006).

Comprehensive reviews on the utilisation of active and/or intelligent packaging systems for meat and muscle based products have been published by Kerry et al. (2006) and Coma (2008), and more recently by Sun and Holley (2012) and Arvanitoyannis and Stratakos (2012). Active and intelligent packaging is a very dynamic field with continuous advancements. Thus, the aim of this review is to provide an update of the current commercial applications as well as to present an overview of research trends and innovations in active and intelligent packaging systems for muscle based foods. Concluding remarks include future trends and expected growth of active and intelligent packaging systems in food preservation.

\section{Active packaging of muscle foods: concepts and commercial applications}

Packaging has traditionally been used to extend the shelf life of muscle foods by providing an inert barrier to external conditions. Active packaging is one of the innovative food concepts that has been introduced in response to the continuous changes in consumer demands and market trends (Vermeiren, Devlieghere, van Beest, de Kruijf, \& Debevere, 1999). This technology is based on the concept of incorporation of certain components into packaging systems that release or absorb substances from or into the packed food or the surrounding environment so as to prolong shelf life and sustain the quality, safety and sensory characteristics of the food (Camo, Antonio Beltrán, \& Roncalés, 2008; Vermeiren et al., 1999). The development of a whole range of active packaging systems is fairly new (Kerry et al., 2006). Most important active packaging concepts applied to muscle foods include moisture absorbers, antimicrobial packaging, carbon dioxide emitters, oxygen scavengers, and antioxidant packaging. This section provides different types of active packaging concepts and an update of commercial applications applied to muscle foods which are outlined in Table 1.

\subsection{Moisture absorbers}

Excess water developed inside the package of high water activity products such as muscle based foods promotes bacterial and mould growth, resulting in quality losses and a reduction of shelf life. The control of excess moisture in food packages is important to inhibit microbial growth and enhance product presentation. An effective way of controlling excess water accumulation in a food package that has a high barrier to water vapour is to use a moisture absorber (Ozdemir \& Floros, 2004). The most common moisture absorbing systems consist of a super absorbent polymer located between two layers of a microporous or nonwoven polymer. This material is supplied as sheets of various sizes that are used as dripabsorbing pads typically found in tray-formatted (overwrap and modified atmosphere) fresh muscle food products (Kerry et al., 2006).

Some examples of absorbing pads used for meat and fish packaging are Cryovac ${ }^{\circ}$ Dri-

Loc $^{\circ}$ (Sealed Air Corporation), MoistCatc ${ }^{\text {TM }}$ (Kyodo Printing Co., Ltd.), and MeatGuard ${ }^{\circ}$ (McAirlaid Inc.). More advanced moisture absorbing systems consist of multilayer materials that include an absorbing layer. LINPAC Packaging Ltd. offers a range of absorbing PP or PET 
trays for meat and fish packaging that consist of an in-built patented high capacity absorbent core (LINPAC, 2013). Similarly, we find the Fresh-R-Pax rigid containers from Maxwell Chase Technologies LLC (Maxwell Chase Technologies, 2014). The absorbent technology comprises a patented blend of materials that comply with both FDA and EU food contact regulations. Another interesting solution for vacuum packaging of red meats has been launched by SEALPAC GmbH. The TenderPac presents a dual-compartment packaging system consisting of a flexible PA/PE film and a second compartment separated by a porous seam where drip loss from meat is diverted. The absorbing compartment is covered by a pre-printed film or label that neatly collects the drip loss and ensures hygienic storage and an attractive presentation that remains during the entire shelf life. The product has an innovative presentation as it allows vertical display in the retail shelves (SEALPAC, 2014b). Finally, Nor Absorbit (Nordenia International $A G$ ) is an example of a moisture-absorbing flexible microwavable packaging material. During microwave cooking Nor Absorbit films are able to absorb excess grease and water released by packed foods (e.g. breaded foods) resulting in crispy products. The absorbing material would replace the use of microwave susceptors (Mondi, 2011).

\subsection{Antimicrobial packaging}

Muscle based products provide excellent growth media for a variety of microorganisms. Microbial growth accelerates changes in the aroma, colour and texture of food resulting in shelf life reduction and increased risk of foodborne illnesses. The development of antimicrobial packaging presents a promising approach to actively control the growth of microorganisms (Kerry, 2014; Kerry et al., 2006). Antimicrobial food packaging materials extend the lag phase and reduce the growth phase of microorganisms in order to extend shelf life and to maintain food quality and safety (Han, 2000). Antimicrobial packaging materials have to be in direct contact with the food surface if they are non-volatile and can be either immobilised on the materials surface or migrate into the food. Therefore, antimicrobial packaging is effective on food products were the microbial contamination occurs at the surface (Appendini \& Hotchkiss, 2002).

Although significant research progress has been made, antimicrobial packaging has had limited commercial success except for silver based antimicrobial materials which are common in countries such as Japan and USA. The use of silver based antimicrobials are expected to grow in Europe after their inclusion in the provisional list of additives for use in food contact materials and in the list of surface biocides in the framework of the Biocides Product Regulation (European Commission, 2011, 2012b). An important number of antimicrobial silver-based masterbatches are available in the market: Biomaster, Aglon, Irgaguard ${ }^{\circ}$, Surfacine ${ }^{\circ}$, IonPure ${ }^{\circ}, d_{2} p^{\circ}$, Bactiblock ${ }^{\circ}$. Linpac Packaging Ltd. has teamed up with

Addmaster to develop a range of antimicrobial trays and lidding solutions containing Biomaster silver-based additive to reduce the growth of foodborne pathogens such as Salmonella, Escherichia coli and Campylobacter in fresh meat (LINPAC, 2012). Similarly, Foodtouch ${ }^{\circ}$ from Microbeguard Corp. is an antimicrobial specialty paper containing Agion silver based additive (Sciessent LLC) used as interleavers for fresh fish fillets during transportation in boxes (Agion, 2007). Nanopack Technology and Packaging SL in collaboration with IRTA is developing a range of interleavers (Sanic films) able to extend the shelf life of vacuum packed meat products (Nanopack, 2014).

Some companies offer other antimicrobial packaging solutions for meat products. SANICO $^{\circ}$ (Laboratories STANDA) is a natamycine-based antifungal coating for sausages (Laboratories STANDA, 2014b). Mitsubishi-Kagaku Foods Corp. has developed Wasaouro ${ }^{\mathrm{TM}}$ an antimicrobial material containing allyl isothiocyanate (Mitsubishi-Kagaku Foods Corporation, 2002), a natural antibacterial and antifungal substance, and it is available in a variety of formats (sheets, labels and films). 


\subsection{Carbon dioxide emitters}

Another active packaging solution with antimicrobial effect is based on carbon dioxide generators. Increased $\mathrm{CO}_{2}$ levels (10-80\%) are desirable for meat and poultry preservation, because they can efficiently reduce the surface microbial growth and thus prolong the shelf life of the product (Vermeiren et al., 1999). This type of active packaging is frequently associated with modified atmosphere (MAP) systems in order to balance out $\mathrm{CO}_{2}$ losses due to dissolution into the meat and permeation through the packaging material (Coma, 2008). $\mathrm{CO}_{2}{ }^{\circ}$ Fresh Pads $\left(\mathrm{CO}_{2}\right.$ Technologies) are used for meat, poultry, and seafood packaging $\left(\mathrm{CO}_{2}\right.$ Technologies, 2014). Drip losses from muscle foods are absorbed into pads and react with citric acid and sodium bicarbonate present in the pad resulting in the generation of carbon dioxide (Kerry et al., 2006). Paper Pak Industries have launched UltraZap XtendaPak pads, a more evolved version of $\mathrm{CO}_{2}$ generators. It is designed as an absorbent pad for fresh meat, poultry and fish that has a double antimicrobial effect due to the incorporation of a $\mathrm{CO}_{2}$ emitter and an antimicrobial substance (Paper Pak Industries, 2014). According to the information contained in the patent, the antimicrobial agent used would mainly consist of a mixture of citric and sorbic acids (Riehle \& Versteylen, 2010). A recent $\mathrm{CO}_{2}$ emitter application has been developed for fish fillets by a Norwegian company, Vartdal Plastindustri AS, also available for meat packaging (Vartdal Plastindustri, 2009). The SUPERFRESH system consists of a coated expanded polystyrene box with a $\mathrm{CO}_{2}$ emitter. The fillets are packed in MAP and when the emitter absorbs fluids from the fillets it activates $\mathrm{CO}_{2}$ emission. Reported system advantages are prolonged shelf life, reduced transport volume, less environmental impact and no bulging or vacuum effect.

\subsection{Oxygen scavengers}

The presence of oxygen in packed food is a key factor that compromises the shelf life of muscle foods. Oxygen is responsible for oxidation of food constituents and proliferation of aerobic bacteria and moulds resulting in quality losses due to changes in flavour, colour, texture and nutritive value, and therefore in a reduction of meat shelf life (Brody, Strupinsky, $\&$ Kline, 2001). The deterioration in quality of oxygen sensitive products can be minimised using oxygen absorbing systems that remove the residual oxygen after packaging (Suppakul, Miltz, Sonneveld, \& Bigger, 2003). The combined use of oxygen scavengers with modified atmosphere packaging or vacuum packaging assures the almost completely removal of oxygen from the package headspace and dissolved in the product. Oxygen scavengers are able to reduce the residuals of oxygen in the package to less than $0.01 \%$ as stated by some manufacturers (Vermeiren, Heirlings, Devlieghere, \& Debevere, 2003). The action of oxygen scavengers helps to minimise the effects of oxygen permeation through the packaging material during product shelf life. Complete removal of oxygen is especially indicated for processed meat products such as cooked ham or fermented sausages, where oxygen traces present in the package can induce photo-oxidation processes when exposed to store lighting, leading to a rapid discoloration (Coma, 2008). Existing oxygen scavenging technologies are mainly based on iron powder oxidation, ascorbic acid oxidation, photosensitive dye oxidation, enzymatic oxidation (e.g. glucose oxidase and alcohol oxidase), unsaturated fatty acids (e.g. oleic or linolenic acid) or immobilised yeast on a solid substrate (Floros, Dock, \& Han, 1997).

The use of oxygen scavenging systems for muscle food packaging has been commercially available for some time. The first systems developed consisted of the inclusion of an oxygen scavenging sachet in the package. Among them we find Oxy-Guard ${ }^{\text {TM }}$ (Clariant Ltd.) based on iron oxidation, OxyCatch ${ }^{\mathrm{TM}}$ (Kyodo Printing Company, Ltd.) where oxygen is absorbed by cerium oxide particles, and FreshPax (Multisorb Technologies, Inc.), a palladium metal and hydrogen gas-based oxygen absorber where palladium catalyses the reaction between hydrogen and oxygen, forming water (Clariant, 2013; EFSA, 2014; Kyodo Printing, 2013). The 
evolution of oxygen scavenging systems lead to the development of oxygen scavenging labels such as ATCO labels from Laboratories STANDA that are able to scavenge levels of oxygen as high as 100-200 $\mathrm{cm}^{3}$ (Kerry, 2014; Laboratories STANDA, 2014a). Iron based Ageless labels (Mitsubishi Gas Chemical Company, Inc.) can absorb oxygen during refrigeration and at freezing conditions at a lower rate (Mitsubishi Gas Chemical, 2009a).

However, the trend in commercial applications is to incorporate oxygen scavengers to the packaging material in order to avoid the negative perception by consumers caused by the presence of a non-edible artefact together with the food, eliminating the risk of accidental rupture of the sachets and ingestion of their contents (Suppakul et al., 2003). Cryovac ${ }^{\circ}$ OS2000 (Sealed Air Corporation, USA) is a polymer-based oxygen scavenging multilayer flexible film activated by ionising radiation (Speer, Edwards, Beckwith, Rivett, \& Kennedy, 2009). According to the manufacturer it can reduce the oxygen levels in the headspace from $0.4 \%$ to below $0.1 \%$ in about 1 week (Sealed Air, 2013). Bioka Ltd. manufactures an enzyme-based oxygen scavenger film based on glucose oxidase/catalase (Bioka, 2014). RPC Bebo Plastik GmbH has launched a rigid oxygen scavenging system consisting of high barrier container made in $\mathrm{PP} / \mathrm{EVOH} / \mathrm{PP}$ for the ready meals market (AIPIA, 2013a). The scavenging activity is obtained by the addition of Shelfplus $\mathrm{O}_{2}$ masterbatch (Albis Plastic $\mathrm{GmbH}$ ), available in various base materials such as PP, PE or EVA (ALBIS, 2014).

More recently, the offer of oxygen scavenging systems has been improved by using materials suitable for high temperature applications such as hot fill and retort. Oxygen scavenging from the gas phase can be achieved within minutes at retort temperatures and within several hours to one or two days at room temperature (Day, 2008). Oxygen scavenging will happen just after packaging resulting in a significant food quality improvement. In this sense, Mullinix Packages Inc. claims that their OxyRx ${ }^{\mathrm{TM}}$ oxygen scavenging PET containers are able to completely prevent oxygen permeation for four years. It is presented as an alternative to cans and glass containers for packaging of convenience prepared foods (AIPIA, 2013b). The OxyRx ${ }^{\mathrm{TM}}$ material can also be crystallized into CPET packaging for microwave and conventional oven heating. Mitsubishi Gas Chemical, Inc. has also developed an iron based oxygen absorbing film $\mathrm{OMAC}^{\circ}$, able to support high temperatures and suitable for retort and hot fill of meat and fish products (Mitsubishi Gas Chemical, 2009b).

\subsection{Antioxidant packaging}

An alternative to oxygen scavenging to prevent food oxidation by active packaging is the inclusion of antioxidants in packaging materials. Oxidative processes are one of the primary mechanisms of quality deterioration in meat and meat products (Liu, Dai, Zhu, \& Li, 2010). Thus, different antioxidants have been used successfully to inhibit oxidation in muscle foods (Mitsumoto, O'Grad, Kerry, \& Buckley, 2005). However, the incorporation of antioxidants in food formulations may affect food quality parameters such as colour or taste and there is a consumer preference for exclusion of additives in foods. Active packaging represents an innovative strategy to incorporate antioxidants in a polymer to prevent oxidative processes and extend the shelf life of food products. Bolumar, Andersen, \& Orlien (2011) identified several advantages of this technology compared with direct addition of antioxidants such as lower amounts of active substances required, localized activity, controlled release of antioxidants, and elimination of processing steps such as mixing, immersion or spraying. Antioxidant agents can be applied into the packaging systems in different forms (sachets, labels, coating or immobilization on packaging material surface, incorporated into the polymer matrix, multilayer films). Extensive research has been conducted looking at the effect of antioxidant packaging systems in controlling oxidative processes in muscles foods, but limited commercial applications have been found. Artibal SA has developed an antioxidant film coating (ATOX) containing oregano essential oils at different concentrations suitable for MAP 
packaging of fresh meat. The film coating performance is based on inhibiting lipid and colour oxidation of beef and lamb and preventing bone discolouration in lamb (Artibal, 2014).

\subsection{Other active packaging systems}

FreshCase packaging (Bemis Company Inc.) is a special active packaging solution that allows red colour formation in vacuum-packed meat. The packaging system consists of a multilayer film containing sodium nitrite that is converted to nitric oxide gas when it comes in contact with meat. The nitric oxide gas combines with myoglobin in the meat to give the typical red colour of fresh beef (Bemis-Curwood, 2014).

Finally, there are a variety of active packaging solutions specially developed for microwave heating. Microwave cooking became popular because of its rapid speed of food preparation, consumer demand for convenient foods, and the rapid growth of foods developed specifically for microwave preparation. However, microwave heating presents a particular type of heat transfer that produces non-uniform energy absorption, which leads to uneven temperature distribution in food (Ryynanen, Risman, \& Ohlsson, 2004). Heterogeneous heating by microwave has been reported in fresh and marinated beef muscles (Pérez-Juan, Kondjoyan, Picouet, \& Realini, 2012). Thus, microwavable active packaging is designed to ameliorate the heating behaviour of the food by shielding, field modification and the use of susceptors (Regier, 2014). Shielding can be applied to achieve more even heating and desired and controlled differential heating of different portions of the food. Modifiers for microwave heating consist of a series of antenna structures, which alter the way microwaves arrive at food thereby resulting in even heating, surface browning and crisping (Ahvenainen, 2003). Microwave susceptors consist of aluminium or stainless steel deposited on substrates such as polyester films or paperboard and serve to dry, crisp and ultimately brown microwave food (Perry \& Lentz, 2009). There are a range of commercially available materials that act as microwave susceptors such as Sira-Crisp ${ }^{\mathrm{TM}}$ susceptors (Sirane Ltd.) and SmartPouch ${ }^{\circ}$ (VacPac Inc.) (Sirane, 2011; VacPac, 2014). Examples of commercial applications are listed by Bohrer (2009) for lasagne and meat pies, and by Regier (2014) for frozen entrees, hot dogs, pizza and sandwich as meat-containing foods. Steam valves that allow release of the vapour created during microwave heating are other active components of packaging. Flexis ${ }^{\mathrm{TM}}$ Steam Valve (Avery Dennison Corp.) and MicVac (SEALPAC GmbH) are examples of valves that allow steam release once a defined pressure point is reached (Avery Dennison, 2011; SEALPAC, 2014a).

\section{Active packaging of muscle foods: research trends and innovations}

\subsection{Antimicrobial packaging}

Comprehensive reviews describing the principles of antimicrobial packaging and reviewing the ongoing research are available (Appendini \& Hotchkiss, 2002; Cha \& Chinnan, 2004; Coma, 2008; Suppakul et al., 2003; Vermeiren, Devlieghere, \& Debevere, 2002). An updated overview of recent trends in antimicrobial research is presented in this section, with special emphasis on the antimicrobials with the greatest potential. Bacteriocins produced by lactic acid bacteria (LAB) are cationic, hydrophobic, and amphiphilic peptides, with a broad spectrum of antimicrobial activity, mainly against Gram-positive bacteria (Aymerich et al., 1996; Ray, 1992; Tagg, Dajani, \& Wannamaker, 1976). Nisin is the only bacteriocin approved as an additive for meat products in some countries such as USA and Australia (FSANZ, 2007; FSIS, 2002; Hereu, Bover-Cid, Garriga, \& Aymerich, 2012). Many research groups have developed antimicrobial solutions for meat packaging containing nisin in order to delay the growth of spoilage microorganisms and foodborne pathogens (Kim, Paik, \& Lee, 2002; Marcos, Aymerich, Garriga, \& Arnau, 2013; Millette, Le Tien, Smoragiewicz, \& Lacroix, 2007; Nguyen, Gidley, \& Dykes, 2008). However, the most recent reports explore the combination of nisin with other 
preservatives in order to cover a wider spectrum of action. In this sense, Basch, Jagus, and Flores (2013) reported the synergistic effect of nisin and potassium sorbate incorporated in tapioca starch-hydroxypropyl methylcellulose films against Listeria innocua and Zygosaccharomyces bailii in vitro. Jofré, Garriga, and Aymerich (2007) found that vacuum packaging of sliced cooked ham using interleavers containing nisin $\left(200 \mathrm{AU} / \mathrm{cm}^{2}\right)$ and potassium lactate $(1.8 \%)$ were the most effective strategy to inhibit $L$. monocytogenes growth. Nisin-disodium ethylenediamine tetraacetic acid (EDTA) solutions used to activate plastic barrier films proved to be effective to reduce the levels of spoilage microorganisms in vacuum packed fresh beef (Ercolini et al., 2010; Ferrocino et al., 2013; La Storia, Mauriello, Villani, \& Ercolini, 2013). The main drawback of using commercial extracts of nisin is their low content of nisin (2.5\% Delvo ${ }^{\circledR}$ Nis, Royal DSM and Nisaplin ${ }^{\circledR}$, Danisco), therefore big amounts of the extract need to be added to the films to obtain an antimicrobial effect. Considering that bacteriocins are natural additives derived from bacterial growth, it is expected that more bacteriocins will be allowed to be used as meat additives. Many research efforts have been done on the development of antimicrobial films using other semi-purified bacteriocins. Among them, enterocins produced by Enterococcus faecium have proved to be effective for controlling L. monocytogenes growth in meat products (Ananou et al., 2005; Aymerich, Garriga, Jofré, Martín, \& Monfort, 2006; Aymerich et al., 2000; Marcos, Aymerich, Monfort, \& Garriga, 2007; Vignolo et al., 2000). Pullulan films containing sakacin A (1 mg/ $\left.\mathrm{cm}^{2}\right)$ produced by Lactobacillus sakei also proved to be effective against $L$. monocytogenes growth, inducing a 3 log reduction in turkey breast during 3 weeks of refrigerated storage (Trinetta, Floros, \& Cutter, 2010). Finally, Blanco Massani et al. (2014) were able to control the growth of $L$. innocua in the surface of wiener sausages packed with antimicrobial films containing lactocins. Another approach to incorporate bacteriocins into antimicrobial packaging is the use of living bacteria. Concha-Meyer, Schobitz, Brito, and Fuentes (2011) were able to inhibit the growth $L$. monocytogenes for 28 days in smoked salmon vacuum packed with alginate films containing bacteriocin producing LAB strains.

Inspired in the hurdle technology a group of researchers has advanced in the study of the combined effect of bacteriocin-containing films and high pressure processing (HPP). The combined strategy has proved to be effective to reduce $L$. monocytogenes levels and to eliminate Salmonella spp. in vacuum packed cooked ham (Jofré, Aymerich, \& Garriga, 2008; Jofré et al., 2007). Marcos, Aymerich, Monfort, and Garriga (2008a) evidenced the efficiency of the combined strategy by showing no recovery of L. monocytogenes in pressurised cooked ham packed with enterocin containing films after a cold chain break. However, the antimicrobial effects of HPP are strongly dependent on food water activity. Therefore, the synergistic antimicrobial effect might be compromised in meat products with $\mathrm{a}_{\mathrm{w}}$ values below 0.9 such as some dry cured hams or fermented sausages (Hereu et al., 2012; Marcos et al., 2013).

Significant research efforts are being conducted regarding the use of natural extracts and essential oils for antimicrobial packaging of muscle based products. Natural extracts and essential oils are rich in phenolic compounds that exert an antimicrobial and antioxidant effect (Cha \& Chinnan, 2004). Grapeseed extract (1\%) incorporated in edible starch films was able to control the growth of Brochothrix thermosphacta on the surface of pork loins during 4 days (Corrales, Han, \& Tauscher, 2009). Essential oils (e.g. garlic, oregano and thyme) and their components (e.g. carvacrol and thymol) have proved to be effective in delaying the growth of spoilage microorganisms in muscle food products (Cerisuelo et al., 2013; Emiroglu, Yemis, Coskun, \& Candogan, 2010; Galotto, Valenzuela, Rodriguez, Bruna, \& Guarda, 2012; Jouki, Yazdi, Mortazavi, Koocheki, \& Khazaei, 2014; Sung et al., 2014). Sirocchi et al. (2013) placed special emphasis on the reduction of biogenic amine production as indicators of meat hygiene in fresh meat packed with films containing rosemary essential oil. Other researchers have focused their efforts on the inhibition of foodborne pathogens such as Salmonella typhimurium (oregano oil) and E. coli O157:H7 (oregano, cinnamon, allyl isothiocyanate) 
(Nadarajah, Han, \& Holley, 2005; Oussalah, Caillet, Salmiéri, Saucier, \& Lacroix, 2006). More recently, Song, Lee, Al Mijan, and Song (2014) reported a reduction of E. coli O157:H7 and L. monocytogenes in smoked salmon packed with composite films of chicken feather protein and gelatin incorporated with clove oil (1.5\%). Similarly, Sung et al. (2014) were able to significantly delay the growth of $L$. monocytogenes in LDPE films with $2 \%$ garlic oil incorporated during masterbatch production. The antimicrobial effect of active packaging systems containing volatile essential oils might be compromised if the volatile substance is not properly retained during film storage. Dias et al. (2013) developed an antimicrobial cellulose film containing allyl isothiocyanate encapsulated in carbon nanotubes that was effective in reducing microbial contamination in RTE chicken meat.

One of the most innovative synthetic antimicrobial agents is ethyl- $\mathrm{N}^{\alpha}$-dodecanoyl-Larginate hydrochloride (LAE) (Higueras, López-Carballo, Hernández-Muñoz, Gavara, \& Rollini, 2013). The antimicrobial properties of LAE are due to its action as cationic surfactant on the cytoplasmic and the outer membrane of Gram-negatives, and the cell membrane and the cytoplasm of Gram-positives. These changes produce disturbances in membrane potential, resulting in cell growth inhibition and loss of viability (Infante, Pinazo, \& Seguer, 1997; Luchansky et al., 2005). LAE containing films have proved to be effective in inhibiting a broad range of microorganism such as LAB, E. coli, Salmonella, L. monocytogenes in in vitro studies (Muriel-Galet, López-Carballo, Gavara, \& Hernández-Muñoz, 2012). Furthermore, Higueras et al. (2013) observed a relevant antimicrobial activity against spoilage microorganisms in fresh chicken breast packed with chitosan films containing $5 \%$ LAE.

An alternative to the incorporation of antimicrobial compounds during extrusion is to apply the antimicrobial additives as food coatings. This strategy has the advantage of placing the specific antimicrobial additive in a controlled manner without subjecting it to the high temperatures reached during the extrusion process (Coma, 2008). Datta, Janes, Xue, Losso, and La Peyre (2008) reported reductions of L. monocytogenes and Salmonella anatum counts in smoked salmon coated with calcium alginate containing lysozyme with or without nisin. Similarly, alginate-based coatings containing sodium lactate $(2.4 \%)$ and potassium sorbate $(0.3 \%)$ were able to significantly reduce $L$. monocytogenes counts in RTE poultry products (Juck, Neetoo, \& Chen, 2010). Other authors have succeeded in extending the shelf life of muscle based food products coated with an antimicrobial polysaccharide, chitosan, alone or in combination with other antimicrobial substances such as essential oils (Ojagh, Rezaei, Razavi, \& Hosseini, 2010; Yingyuad et al., 2006).

The incorporation of an antimicrobial into a package might alter the mechanical and barrier properties of packaging materials. Certain antimicrobials can act as plasticizers, improving the tensile properties, but they can also have detrimental effects on film strength, crystallinity and barrier properties (Bastarrachea, Dhawan, \& Sablani, 2011; Corrales, Fernández, \& Han, 2014; Marcos, Aymerich, Monfort, \& Garriga, 2010; Scaffaro, Botta, Marineo, \& Puglia, 2011). The use of antimicrobial nanoparticles with enlarged contact area compared to conventional antimicrobial compounds might allow the reduction of the amount of antimicrobial substances to be added due to the enhanced antimicrobial activity of nanocompounds. Nano-sized components have shown potential to improve the properties of packaging materials applied to muscle foods (Brody, Bugusu, Han, Sand, \& McHugh, 2008; Picouet, Fernandez, Realini, \& Lloret, 2014). Heavy metals are effective antimicrobials in the form of salts, oxides, and colloids, added as complexes such as silver zeolites, or as elemental nanoparticles (Llorens, Lloret, Picouet, Trbojevich, \& Fernandez, 2012). Cellulose absorbent pads containing silver nitrate nanoparticles proved to be effective to control the population of spoilage microorganisms in beef (Fernández, Picouet, \& Lloret, 2010; Lloret, Picouet, \& Fernández, 2012). Akbar and Anal (2014) developed a sodium alginate films containing zinc oxide nanoparticles able to eliminate S. typhimurium and Staphylococcus aureus in RTE poultry meat. 
Although extensive research has been carried out in the development of antimicrobial packaging solutions, this type of active packaging has had limited commercial success. The main constraints for the commercialization of antimicrobial packaging systems are mainly regulatory issues and also technical limitations that need to be solved. To successfully implement antimicrobial packaging solutions in the market, a multidisciplinary approach involving researchers from different disciplines (food, microbiology, and material science) working together with the packaging industry will be necessary.

\subsection{Carbon dioxide emitters}

Commercial examples of carbon dioxide emitters applied in muscle based foods incorporated in the form of sachets and absorbent pads were previously presented and discussed. Carbon dioxide emitters have been tested on packaging of salmon (Hansen et al., 2009) and cod fillets (Hansen, Morkore, Rudi, Olsen, \& Eie, 2007), obtaining similar or longer microbiological shelf life than vacuum packaging. Carbon dioxide emitters allow the reduction of the packaging headspace by reducing the gas to product volume ratio compared to optimal MAP. This means improved transport efficiency of modified atmosphere packages without compromising quality and shelf life. Holck, Pettersen, Moen, and Sørheim (In Press) recently prolonged shelf life, avoided collapse of the packages which caused a reduction of drip loss of chicken fillets by the use of carbon dioxide emitters and MAP.

The growth and development of the $\mathrm{CO}_{2}$ emitter market is likely to progress towards the development of films that incorporate the carbon dioxide emitter functionality (Day, 2008). Although research into this concept is still in its early stages, a recent application on the use of active packaging structures to control the microbial quality of a ready-to-eat meat products has been tested by Chen and Brody (2013). Cooked ham samples were packed into three antimicrobial packaging structures including a nylon/EVOH/polyethylene oxygen barrier bag and an antimicrobial film (CSP Technologies, three-phase Activ-Polymer technology, US Pattent $7,005,459)$ with the capacity of generating $\mathrm{CO}_{2}$ or generating allyl isothiocyanate or scavenging $\mathrm{O}_{2}$. Packaging structures with $\mathrm{O}_{2}$ scavengers or $\mathrm{CO}_{2}$ generators proved to control bacterial populations, particularly Listeria, while the allyl isothiocyanate generator only had limited antimicrobial effects.

\subsection{Oxygen scavengers}

Many different types of oxygen scavengers have been successfully applied to eliminate residual oxygen and consequently extend the shelf life of muscle based foods. Commercially available examples have been previously presented and discussed. The role of oxygen scavengers to improve food preservation is a dynamic research area and recent studies are presented and discussed in this section. The most versatile oxygen scavengers are based on oxidation of iron powder. However, metal-based scavengers present several disadvantages (e.g., potential health risk by accidental ingestion by consumers, being detected in metal detectors, causing arcing in microwave heating), and thus, organic-type scavengers have been studied as an alternative. Organic substrates that are easy to oxidize, such as ascorbic acid, catechol, and polyunsaturated fatty acids, have been incorporated into sachets and labels, and more recently into polymer blends (Lee, 2014). Oxygen scavengers based on the inclusion of microorganisms which may have advantages regarding consumer perception and sustainability, have been developed as an alternative to chemical scavengers. Altieri et al. (2004) entrapped microorganisms (Kocuria varians and Pichia subpelliculosa) into hydroxyethyl cellulose and polyvinyl alcohol and maintained their viability over 20 days. Anthierens et al. (2011) incorporated Bacillus amyloliquefaciens spores as an active agent in polyethylene terephthalate, 1,4-cyclohexane dimethanol. Incorporated spores could actively consume oxygen for minimum 15 days, after an activation period of $1-2$ days at $30^{\circ} \mathrm{C}$ under high 
humidity conditions. Enzymes such as glucose oxidase/catalase have also been proposed as oxygen scavenging systems (Lee, 2010). Recently, enzymes embedded in barrier coatings for active packaging have been tested in food applications (Järnström et al., 2013). It was demonstrated that the developed active coatings can be used to hinder oxidation and rancidity reactions of packed food such as fish stored at chilled conditions.

The oxygen barrier behaviour of polymer films can be significantly improved by incorporating unsaturated functional groups that provide oxygen absorption capacity (Ferrari et al., 2009). The autoxidation reaction in the polymer is triggered by ultraviolet light with the aid of transition metal catalysts. Byun, Darby, Cooksey, Dawson, and Whiteside (2011) developed an effective oxygen scavenging system containing a natural free radical scavenger ( $\alpha$-tocopherol) and a transition metal that does not require an ultraviolet light activation step. In another study, Byun, Bae, and Whiteside (2012) demonstrated the oxygen scavenging capacity of a system composed of $\alpha$-tocopherol-loaded nanoparticles and iron chloride incorporated into fish gelatine films. Byun and Whiteside (2012) also produced and evaluated an ascorbyl palmitate- $\beta$ - cyclodextrin inclusion complex that can be used as an effective oxygen scavenger. The inclusion complex showed thermal and chemical stability, might be extruded to produce an oxygen scavenging film, and might be used in thermal processing applications such as retort pouches. Particular attention has been focused on the photocatalytic activity of nanocrystalline titania under ultraviolet radiation. Oxygen scavenger films were successfully developed by adding titania nanoparticles to different polymers (de Azeredo, 2009; Mills, Doyle, Peiro, \& Durrant, 2006; Xiao-e, Green, Haque, Mills, \& Durtant, 2004). The photocatalytic activity of nanocrystalline $\mathrm{TiO}_{2}$ on polymer surfaces can oxidize organic substances to consume oxygen and produce carbon dioxide. Films containing photocatalytic titanium are also known to inactivate microorganisms and thus have potential as antimicrobial packaging material (Lee, 2014). Busolo and Lagaron (2012) recently evaluated high barrier oxygen scavenging polyolefin nanocomposite films containing an iron modified kaolinite of interest in active food packaging applications. The results showed significant potential for the technology as an active packaging able to trap and react with molecular oxygen for shelf life extension of oxygen sensitive food products. Recent advances suggest that oxygen scavengers offer new opportunities in preserving the quality and extending the shelf life of muscle foods. However, further applied research and development are needed by adjusting the different concepts to the conditions of the packaging and the food industries.

\subsection{Antioxidant packaging}

Research on active packaging for muscle foods has focused predominantly on the use of antimicrobial agents, while the development of antioxidant applications is growing. Active substances with different mechanisms of action have been investigated, and the current trend is to reduce the use of synthetic additives in packaging and their substitution by natural antioxidants, particularly tocopherol. Plant extracts, and essential oils from herbs such as rosemary, oregano, and tea, are of great interest as natural antioxidants, in most cases can offer health benefits, and their use is becoming highly relevant to muscle foods (BarbosaPereira, Aurrekoetxea, Angulo, Paseiro-Losada, \& Cruz, 2014; Mc Carthy, Kerry, Kerry, Lynch, \& Buckley, 2001; Pereira de Abreu, Paseiro Losada, Maroto, \& Cruz, 2010, 2011).

Recently developed films with natural antioxidants have been successfully tested in direct contact with muscle foods as active packaging systems. Park et al. (2012) vacuum packed fresh beef patties using films with phenolic compounds and effectively inhibited lipid oxidation and improved colour stability of patties during storage. Similarly, Giménez, GómezGuillén, Pérez-Mateos, Montero, and Márquez-Ruiz (2011) showed improvement in oxidative stability of mackerel patties covered with borage seed extract-containing film during storage. Barbosa-Pereira et al. (2014) reported a reduction in lipid oxidation by up to $80 \%$ in beef wrapped in films coated with natural extracts obtained from a brewery residual waste. López- 
de-Dicastillo, Gómez-Estaca, Catalá, Gavara, and Hernández-Muñoz (2012) tested the efficiency of EVOH films with natural flavonoids (ascorbic acid, ferulic acid, quercetin, and green tea extract) on the lipid stability of wrapped brined sardines, and showed protection against lipid oxidation, particularly by the films with green tea extract. Pereira de Abreu et al. (2011) also increased the oxidative stability of blue shark muscle wrapped with films containing natural antioxidants derived from barley husks. Active packaging systems with antioxidant components in direct contact with the product are suitable for sliced meat and meat products and those that are wrapped with the film or vacuum packed. Other antioxidant packaging systems have been successfully developed to retard oxidation during storage with no direct contact between the active film and the packed food as in modified atmosphere packaging. The oxidative stability of modified atmosphere packed beef and lamb steaks was significantly improved by using active films with oregano and rosemary extracts (Camo et al., 2008; Camo, Lorés, Djenane, Beltrán, \& Roncalés, 2011; Nerín et al., 2006). Torrieri et al. (2011) also demonstrated that MAP in combination with active packaging is a valuable tool to increase the shelf life of tuna fillets.

Metal-chelating active packaging is another promising novel approach to control lipid oxidation in food, however, not much research has been conducted in this area (Tian, Decker, \& Goddard, 2013). Ünalan, Korel, and Yemenicioglu (2011) incorporated $\mathrm{Na}_{2}$ EDTA into films to inhibit the lipid oxidation of ground beef patties. Lee (2014) highlighted the need for active packaging that provides antioxidant and antimicrobial functions since many natural essential oils contain ingredients with both activities (Sacchetti et al., 2005). Antimicrobial and antioxidant chitosan films have been developed with the addition of green tea extract and rosemary essential oil for food packaging (Abdollahi, Rezaei, \& Farzi, 2012; Siripatrawan \& Harte, 2010). Calatayud et al. (2013) developed active films based on cocoa extract with antioxidant and antimicrobial activities. Camo et al. (2008) demonstrated the dual antimicrobial and antioxidant function in lamb using rosemary and oregano active films.

Increasing interest and research has been focused during the last few years on biodegradable packaging materials due to environmental concerns (Rodriguez-Aguilera \& Oliveira, 2009). Antioxidant packaging systems have been developed by incorporating natural antioxidants into biodegradable films. Polylactic acid is a versatile compostable polymer derived from natural source and is easily processed. Recently, $\alpha$-tocopherol has been incorporated into PLA films as antioxidant packaging materials (Youngjae Byun, Kim, \& Whiteside, 2010; Jamshidian et al., 2012; Manzanarez-López, Soto-Valdez, Auras, \& Peralta, 2011). The addition of mango and acerola pulps in cassava starch bio-based film was also tested by Souza et al. (2011), but the high content of vitamin C in acerola pulp was found to be prooxidant. Natural compounds have also been added to edible films in order to confer antioxidant activity, and Coma (2008) indicated that the use of edible films containing essential oils as a preservation method for meat is promising. Blanco-Fernandez, Isabel Rial-Hermida, Alvarez-Lorenzo, and Concheiro (2013) developed edible chitosan films for prolonged release of vitamin E and antioxidant activity. Mounia Oussalah, Caillet, Salmiéri, Saucier, and Lacroix (2004) evaluated the ability of a milk protein-based edible film containing $1 \%$ essential oils of oregano, pimiento or both applied on beef muscle slices, and showed that the pimiento-based films had the highest antioxidant activity. Yingyuad et al. (2006) reported minimized oxidation as determined by peroxide values and colour changes of retail grilled pork using chitosan coating and vacuum packaging. Active packaging can be used in combination with other processing treatments to extend food shelf life. High pressure processing has shown to be an effective technology to improve safety of meat and meat products (Marcos, Aymerich, \& Garriga, 2005; Marcos, Aymerich, Monfort, \& Garriga, 2008; Marcos, Jofré, Aymerich, Monfort, \& Garriga, 2008; Realini, Guardia, Garriga, Perez-Juan, \& Arnau, 2011). However, HPP may accelerate meat oxidation (Cheah \& Ledward, 1996; Ma, Ledward, Zamri, Frazier, \& Zhou, 2007; McArdle, Marcos, Kerry, \& Mullen, 2011; McArdle, Marcos, Mullen, \& Kerry, 2013). Bolumar et al. (2011) reported that antioxidant active packaging was able to delay the 
oxidation induced by HPP and consequently extend the shelf life of chicken patties. The authors concluded that the combination of active packaging and antioxidants for HP processed meat products seems to have market potential.

Antioxidant active packaging is a promising technique for extending food shelf life and even though significant progress has been made through research and innovation, it is a developing technology, and current research is in its early stages. Tian et al. (2013) recently highlighted challenges and key areas for future research including a rigorous evaluation of the retained antioxidant activity and stability after being added into a packaging material, and a particular attention to the characteristics of food products to select suitable active agents and application approaches. Considerations of the engineering properties of packaging materials as influenced by the incorporation of antioxidants, and the migration of active substances from packaging materials were also indicated. Lee (2014) pointed out that maximum effectiveness of antioxidant packaging systems can be achieved by fitting the antioxidant release rate with the lipid oxidation rate. Mathematical models of diffusion probed to be a valuable tool to predict the release profile of antioxidants into food systems (Piringer, 2000). However, further research must be conducted to control the diffusion rate of the bioactive compounds in practical packaging of muscle foods during storage.

\section{Intelligent packaging of muscle foods: concepts and commercial applications}

Intelligent packaging is designed to monitor the condition of the packed food or the environment surrounding the food (European Commission, 2009). An intelligent packaging system is capable of detecting, sensing, recording, tracing, or communicating information about the quality and/or the state of the product during the whole food chain (Yam, Takhistov, \& Miltz, 2005). The package will provide information not only about the product itself (origin, theoretical expiration date, composition), but will also be able to inform about the history of the product (storage conditions, headspace composition, microbial growth, etc.). Therefore, intelligent packaging represents a big step forward to prevent food waste and to improve food logistics and traceability. The intelligent function can be obtained by indicators, sensors and/or devices able to communicate information about the packaging system. Indicators inform about a change occurred in a product or its environment (e.g. temperature, $\mathrm{pH}$ ) by means of visual changes. Indicators with application to muscle food packaging are time temperature indicators, oxygen and integrity indicators and freshness indicators. Biosensors are devices able to detect, record and transmit information related to biological reactions occurring in the package with great precision (Yam et al., 2005). This section provides different types of intelligent packaging concepts and an update of commercial applications applied to muscle foods which are outlined in Table 2.

\subsection{Time temperature indicators (TTI)}

Temperature is one of the most important environmental factors determining food preservation, as variations in temperature during food shelf life can compromise the safety and the shelf life of perishable food products such as muscle based foods. TTls are effective tools designed for continuous monitoring of the time and temperature history of chilled and frozen products throughout the food chain (Lee \& Rahman, 2014). TTls offer an indicator that visually changes with the time elapsed from packaging, a process that is accelerated with increasing temperature (Galagan \& Su, 2008). These indicators allow continuous monitoring of the storage conditions. Therefore, they can inform about a cold chain break and can be used as indirect shelf life indicators. TTI indicators that are available in the market are based on physical, chemical, enzymatic or biological processes (Kerry et al., 2006). 
$3 \mathrm{M}$ Monitor Mark ${ }^{\circ}$ (3M Company) is a TTI containing a fatty acid ester with a selected melting point mixed with a blue dye. Upon exposure to a temperature exceeding a critical value, the substance melts and begins to diffuse through the indicator causing a blue colouring to appear. The range of temperatures $\left(-15\right.$ to $\left.26^{\circ} \mathrm{C}\right)$ and the response life of the TTI are determined by the type and concentration of the ester (3M, 2014; Kerry et al., 2006; Kuswandi et al., 2011). Keep-it Technologies has recently launched Keep-it fresh, a full-history TTI based on a chemical reaction. The system comprises an immobilized reactant, such as $\mathrm{Fe}^{3+}$, and a mobile reactant, such as ferrocyanide, initially contained in separate compartments, and separated by a sealing. The system is activated by removing the sealing between the compartments whereby the mobile reactant in a time-temperature dependent manner is brought into contact with the immobilized reactant resulting in a visually detectable reaction signal (Keep-it Technologies, 2014; Skjervold, Salbu, Heyerdahl, \& Lien, 2007). Another fullhistory TTI is Fresh-Check (Temptime Corp.), based on a polymerization reaction. Diacetylene crystals polymerize via 1,4 addition polymerization resulting in a highly coloured polymer (Kerry et al., 2006; Temptime Corp., 2014). Based on the time-temperature dependence of an enzymatic reaction we find VITSAB (VITSAB International AB) TTI. The indicator consists of two separate compartments containing an aqueous solution of lipolytic enzymes and the substrate consisting mainly of triglycerides and a pH indicator. The $\mathrm{TTI}$ is activated when the wall between the two compartments is broken and the contents are mixed. A colour change from green to clear yellow appears due to the enzymatic hydrolysis of the substrate (Galagan \& Su, 2008; VITSAB, 2013). OnVu ${ }^{\text {TM }}$ is a novel TTI jointly developed by Ciba and Freshpoint ${ }^{\mathrm{TM}}$ based on a photochemical reaction. $\mathrm{OnVu}^{\mathrm{TM}}$ indicators contain benzopyridines, a pigment that changes colour over time at temperature dependant rates. The indicator is activated by exposure to UV light to become dark blue and the colour gradually fades with time. This system can be applied as a label or printed directly onto the package (Freshpoint, 2011c; O'Grady \& Kerry, 2008). Another approach is the use of microbiological TTIs such the one developed by TRACEO. TopCryo $^{\mathrm{TM}}$ is a time-temperature indicator system based on Carnobacterium maltaromaticum and a colour change indicator, acid fuchsin. The micro-organism, the indicator and a nutritive medium gel are incorporated in a multilayer plastic sachet glued onto the outer layer of the food package (EFSA, 2013; Traceo, 2014). Finally we find TTIs such as FreshCode ${ }^{\text {TM }}$ (Varcode Ltd.) and Tempix (Tempix AB) labels based on barcodes printed with fading inks that disappear due to temperature abuse (Tempix, 2014; Varcode, 2014).

\subsection{Integrity indicators}

The most simple integrity indicators are time indicators that provide information about how long a product has been opened. The label is activated at the moment of consumption, when the seal is broken it triggers a timer and experiences a colour change with time. Some commercial examples are Timestrip (Timestrip Ltd.), Novas Embedded Label (Insignia Technologies Ltd.), and Best-by ${ }^{\mathrm{TM}}$ (FreshPoint Lab.) (Freshpoint, 2011a; Insignia Technologies, 2014; Timestrip, 2012).

Gas indicators are the most commonly used integrity indicators for meat packaging applications. They work as leak indicators giving information on package integrity throughout the whole distribution chain. Among the various types of gas indicators, oxygen indicators are the most common indicators used for MAP packaging applications (Yam et al., 2005). MAP of meat products other than fresh meat usually consist of high levels of $\mathrm{CO}_{2}(20-80 \%)$ and a residual concentration of $\mathrm{O}_{2} \quad(<0.1-1 \%$, depending on the efficiency of the packaging equipment). Therefore, a leak in a MAP package will be easily detected using indicators of the level of oxygen. The most common $\mathrm{O}_{2}$ indicators are colourimetric redox dye based indicators comprising a redox dye, such as methylene blue, and a strong reducing agent, such as glucose in an alkaline medium (Mills, 2005). When the redox dye of the indicator is oxidised by oxygen a colour change can be observed. A drawback of this type of $\mathrm{O}_{2}$ indicators is that the colour 
change is reversible and returns to the original form if the concentration of oxygen is reduced. Reversibility is undesirable for leakage control since oxygen entering the package might be consumed due to microbial growth (Hurme, 2003). The main application of $\mathrm{O}_{2}$ indicators is in combination with $\mathrm{O}_{2}$ scavenging systems (Kuswandi et al., 2011). This combination will prevent that the $\mathrm{O}_{2}$ indicator reacts with the residual $\mathrm{O}_{2}$ present in the package.

Ageless Eye tablets (Mitsubishi Gas Chemical Company, Inc.) are reversible oxygen indicators used in combination with AGELESS $\mathrm{O}_{2}$ absorbers. The colour of the tablets changes from pink at levels of $\mathrm{O}_{2} \leq 0.1 \%$ to blue at levels $\geq 0.5 \%$ at a temperature dependent rate. Working with the same principle we find Tell-Tab $\mathrm{O}_{2}$ indicator tablets from IMPAK (Mitsubishi Gas Chemical, 2014; Sorbent Systems, 2014). More recently, EMCO Packaging has launched non-reversible oxygen indicator labels (Emco Packaging, 2013). FreshPoint Lab. has presented $\mathrm{O}_{2}$ Sense $^{\mathrm{TM}}$ a patent pending luminescence $\mathrm{O}_{2}$ indicator label to detect leakages in MAP packages. (Freshpoint, 2011b).

\subsection{Freshness indicators and sensors}

The idea of freshness indicators is that they monitor the quality of the packed food by reacting in one way or another to changes taking place in the fresh food product as a result of microbial growth or metabolism. Therefore, they give direct information about the quality of the product (Smolander, 2008). Chemical changes occurring in meat during storage are indicators of the freshness of muscle based food products. Changes in the concentration of metabolites such as glucose, organic acids (e.g. L-lactic acid), ethanol, carbon dioxide, biogenic amines, volatile nitrogen compounds or sulphuric compounds during storage indicate microbial growth and therefore present the possibility of using them as freshness indicators for meat products (Arvanitoyannis \& Stratakos, 2012). Intelligent packaging systems for monitoring food freshness are found either as freshness indicators based on an indirect detection of metabolites through colour indicators (e.g. pH) or based on direct detection of target metabolites using biosensors. A number of developments by packaging companies have been announced, however in most cases successful commercialization was not achieved.

In 1999, COX Technologies (Plainfield, IL) launched Fresh Tag ${ }^{\circ}$ a colorimetric indicator which informs about the formation of volatile amines in fish products, however, the product was discontinued in 2004 (Kerry, 2014). In 2007, DSM NV announced the development of SensorQ ${ }^{\text {TM }}$ in collaboration with Food Quality Sensor International Inc., a pH-sensing technology based on anthocyanines able to inform about the formation of biogenic amines from microbiological origin in packed meat and poultry (DSM, 2007; Williams, Myers, Owens, \& Bonne, 2006). VTT Technical Research Centre of Finland together with UPM Raflatac developed a freshness indicator for poultry meat based on a nanolayer of silver that reacts with hydrogen sulphide, a breakdown product of cysteine. The indicator is opaque light brown at the moment of packaging, but as silver sulphide is formed the colour of the layer is converted to transparent (Smolander, 2008; UPM, 2007). However, SensorQ ${ }^{\text {TM }}$ and Raflatac indicators are not commercially available at the moment of publication.

Biosensors are intelligent systems able to detect target metabolites that can be incorporated to food packaging. They are able to monitor food freshness in a more specific way than freshness indicators, as they can detect the formation of degradation products and might be designed in a tailored manner according to the type of product being packed. A biosensor is a compact analytical device that detects, records, and transmits information pertaining to biochemical reactions. It consists of two primary components: a bioreceptor that recognizes a target analyte and a transducer that converts biochemical signals into a quantifiable electrical response. Several prototypes of commercial biosensors for intelligent packaging are being developed. Food Sentinel System (SIRA Technologies Inc.) is a biosensor developed to detect food pathogens with a specific-pathogen antibody attached to a membrane forming part of a barcode. The presence of contaminating bacteria causes the 
formation of a localized dark bar, rendering the barcode unreadable upon scanning (Yam et al., 2005). Toxin Alert Inc. also developed a patented diagnostic system, Toxin Guard ${ }^{\mathrm{TM}}$, based on the incorporation of antibodies into plastic films (Yam et al., 2005). However, to the best of our knowledge Food Sentinel System and Toxin Guard ${ }^{\mathrm{TM}}$ are currently not commercially available.

\subsection{Radiofrequency identification tags (RFID)}

Radiofrequency identification (RFID) tags use RF electromagnetic fields to store and communicate real-time information of the product for automatic product identification and traceability (Lee \& Rahman, 2014). The tags consist of an integrated circuit attached to an antenna for the transmission of information stored in the chip to a reader. The main advantages of RFID over barcodes are that they allow a remote control because line-of-sight is usually not required, multiple items can be monitored at the same time, and they have capacity to store diverse information (origin, process parameters, commercial information, etc.) allowing a unique identification of the product (Kuswandi et al., 2011).

There have been important advancements in RFID technology in recent years that have allowed the application of RFID to the food supply chain (Guillory \& Standhardt, 2012). RFID offers a number of potential benefits to the meat production, distribution and retail chain improving traceability, inventory management, and facilitating automation (Mousavi, Sarhadi, Lenk, \& Fawcett, 2002). There are a number of RFID suppliers such as EPSILIA (Canada), RFID Enabled solutions Inc. (USA), and HRAFN Ltd. (Sweden), that have worked together with meat and fish industries to implement RFID systems (Swedberg, 2011, 2012; Wasserman, 2010). More evolved RFID systems allow the integration of other functions into the RFID tag, such as time-temperature indicators or biosensors, to monitor and communicate the temperature history of the product as well as quality information (Guillory \& Standhardt, 2012).

A great advance in the application of RFID has been the integration of TT sensors to RFID devices. TT sensor tags are attached to boxes or pallets during transport allowing tracking of food temperature during the whole food chain. The combined use of RFID and sensor technology applied to the cold chain results in an improvement in supply chain management efficiency and increased savings due to less waste production. Some examples of reusable TT sensor tags designed to provide the temperature history of the product throughout the cold chain processes are Easy2 $\log ^{\odot}$ (CAEN RFID Srl), sensor tag CS8304 (Convergence Systems Ltd.), and TempTRIP sensor tags (TempTRIP LLC) (CAEN RFID, 2014; CSL, 2013). Some packaging manufacturers have incorporated RFID systems into their food boxes. Mondi PIc has presented its Intelligent Box, an RFID-enabled corrugated case that is equipped with an RFID tag at case level, enabling it to be traced throughout the entire supply chain (Mondi, 2014). In line with the new EU regulation that requires fish to be labelled and to assure complete traceability of fish catches, the Craemer Group $\mathrm{GmbH}$ has developed an intelligent fish box. The patent pending intelligent fish box contains an integrated RFID transponder that enables to identify, track and trace information about fish, fishing grounds and the quality and size of the catch (Craemer, 2014).

\section{Intelligent packaging of muscle foods: research trends and innovations}

\subsection{Time-temperature indictors}

As previously described, TTIs are used to monitor the temperature history of a food product. Several authors have studied the capability of commercial TTI to predict the quality of muscle based food products during its shelf life. Brizio and Prentice (2014) reported that $\mathrm{OnVu}{ }^{\circ} \mathrm{TTI}$ constituted a reliable tool to monitor the supply chain of chilled boneless chicken breast. Giannakourou, Koutsoumanis, Nychas, and Taoukis (2005) developed a mathematical prediction model to estimate the growth of Pseudomonas during the shelf life of seabream 
based on the response of a commercial enzymatic TTI (VITSAB ${ }^{\circ}$ ). Ellouze and Augustin (2010) studied the effectiveness of two commercial biological TTI prototypes to predict the growth of spoilage microorganisms and pathogens (L. monocytogenes, Salmonella and S. aureus) in ground beef and chicken slices packed in MAP. The authors concluded that in case of poor storage conditions, TTI could reduce the consumer exposure to altered or hazardous foods. In another study the same authors developed a model to predict the microbial quality and safety (L. monocytogenes) of smoked salmon using the same biological TTIs (Ellouze, Gauchi, \& Augustin, 2011). The prediction models used in the above mentioned studies are based in the temperature dependency of the reactions according to Arrhenius equation. However, when modelling the Arrhenius relationships, there are some problems regarding insufficient data points or non-linearity, thereby leading to significant errors in the predictions (Han, Kim, Shim, \& Lee, 2012). A novel method for modelling temperature dependency using fuzzy reasoning was developed by Han et al. (2012). The authors found that the new method was more accurate to predict beef quality expressed as volatile basic nitrogen from TTI colour than the original method.

The development of TTI to monitor muscle based food quality is object of continuous research. Vaikousi, Biliaderis, and Koutsoumanis (2008) developed a TTI based on the growth of a Lactobacillus sakei. A colour change progressively occurred due to $\mathrm{pH}$ decline resulting from microbial growth and metabolism. In a subsequent study the authors examined the applicability of the TTI to monitor microbial quality of ground beef packed in MAP under isothermal and dynamic storage conditions. The growth of $L$. sakei in the TTI was very similar to the growth of $L A B$ in the meat and the end of product's shelf life coincided with a LAB population level of $10^{7} \mathrm{cfu} / \mathrm{g}$ (Hariklia Vaikousi, Biliaderis, \& Koutsoumanis, 2009). Park, Kim, Jung, Kim, and Lee (2013) developed a TTI based on other LAB (Weissella cibaria) for vacuum packed chicken breast. The authors found that the TTI could be used as an indicator of the growth of coliform bacteria. The same group reported that the quality indicator that better correlated with TTI response in ground pork was total viable counts (Kim, Choi, Kim, Kim, \& Lee, 2013).

\subsection{Integrity indicators}

The use of colorimetric gas sensors based on simple reversible redox reactions for MAP of muscle based food products is well established as previously described. However, these sensors require storage and handling under anaerobic conditions, posing a major problem to their routine use in MAP (Mills, 2005). To tackle this problem Jang and Won (2014) proposed a practical approach of a pressure-activated oxygen indicator. Unlike conventional oxygen indicators, the components of this oxygen indicator are physically separated by a pressureruptured impervious barrier. The oxygen indicator is activated once the package is sealed (i.e. in-pack activation) by breaking the barrier and allowing each component to be in contact with each other. Activation of oxygen indicators by exposure to UV-light has proved to be another effective strategy to protect these indicators until the moment of use (Mills, 2005). Vu and Won (2013) developed a novel $\mathrm{O}_{2}$ indicator that was activated (photobleached) upon exposure to UV light and recovered its original colour in the presence of oxygen. The oxygen indicator films were fabricated using thionine, glycerol, $\mathrm{TiO}_{2}$, and zein as a redox dye, a sacrificial electron donor, UV-absorbing semiconducting photocatalyst, and alginate as encapsulation polymer. The Mills Research Group from Queens University Belfast has developed a series of UV-activated oxygen sensitive inks (Lawrie, Mills, \& Hazafy, 2013; S.-K. Lee, Mills, \& Leprea, 2004; Mills \& Hazafy, 2009; Mills \& Lawrie, 2011). Mills and Lawrie (2011) described a UVactivated colorimetric $\mathrm{O}_{2}$ indicator comprising a redox dye (methylene blue, $\mathrm{MB}$ ), a semiconductor photocatalyst $\left(\mathrm{Pt}_{\mathrm{TiO}}\right.$ ), and a sacrificial electron donor (glycerol), all dispersed in a polymer medium (sulfonated polystyrene, SPS). Upon exposure to UVA light, the Pt$\mathrm{TiO}_{2} / \mathrm{MB} / \mathrm{glycerol} / \mathrm{SPS}$ oxygen indicator is readily photobleached as the MB is converted into its 
oxygen-sensitive leuco form. The authors were able to decrease the recovery times by increasing the level of platinum loading. In another study, Mills \& Hazafy (2009) used a nanocrystalline $\mathrm{SnO}_{2}\left(n c \mathrm{SnO}_{2}\right)$ as a photosensitiser in a colorimetric $\mathrm{O}_{2}$ indicator comprised by $M B$, glycerol, and hydroxyethyl cellulose (HEC) as encapsulating polymer. Upon exposure to UVB light the indicator was activated due to photoreduction of $\mathrm{MB}$ by the $n c \mathrm{SnO}_{2}$ particles. Unlike other $\mathrm{TiO}_{2}$-based $\mathrm{O}_{2}$ indicators, the $\mathrm{HEC} /$ glycerol/MB/ncSnO $\mathrm{O}_{2}-\mathrm{O}_{2}$ indicator is activated by UVB light and not by UVA light from white fluorescent lamps, thus providing much greater control in the activation of the indicator. However, Roberts, Lines, Reddy and Hay (2011) stated that MB was not an ideal electrochrome due to its slow reduction to the leuco form and subsequent fast oxidation at low concentrations of $\mathrm{O}_{2}(>0.1 \%)$ and proposed polyviologen electrochromes as an alternative.

\subsection{Freshness indicators and biosensors}

As previously reported, the number of freshness indicators developed at a commercial level is still very limited. Despite this, a variety of freshness indicators able to monitor chemical changes occurring during food shelf life have been presented in the scientific literature. Most of the concepts are based on a colour change of the indicator tag due to the presence of metabolites derived from microbial growth (Smolander, 2008). Among them we find indicators based on $\mathrm{pH}$ changes that are correlated with the production of some specific metabolites. Yoshida, Maciel, Mendonça, and Franco (2014) developed a colorimetric pH indicator consisting of a chitosan film containing anthocyanin. This kind of $\mathrm{pH}$ indicators offer potential to be used as indicators of metabolites derived from microbial growth such as n-butyrate, Llactic acid, D-lactate and acetic acid (Kerry, 2006). Carbon dioxide produced during microbial growth is another metabolite that can be used as an indicator of food spoilage. Researchers from Sejong University developed $\mathrm{CO}_{2}$ indicators consisting of aqueous solutions of chitosan or whey protein isolate, which transparency changed in a $\mathrm{pH}$ dependent way due to the presence of $\mathrm{CO}_{2}$ (Jung, Puligundla, \& Ko, 2012; Lee \& Ko, 2014). However, further developments would be needed to be able to incorporate these aqueous indicators to intelligent packaging systems. Other authors have focused on the detection of volatile amines, known as total volatile basic nitrogen (TVBN) as freshness indicators in fish. Volatile amines result from the degradation of trimethylamine oxide and are responsible for the fishy odour and flavour commonly used as criteria for assessing the fish quality (Etienne, 2005). Boscher et al. (2014) described the detection of volatile amines such as trimethylamine (TMA), triethylamine (TEA) and dimethylamine (DMA) using a novel metalloporphyrin-based coating applied onto PET films. Pacquit et al. $(2007 ; 2006)$ developed a colorimetric dye-based indicator able to track the increase in volatile amines as an indicator of fish spoilage. The indicator was prepared by entrapping within a polymer matrix a $\mathrm{pH}$-sensitive dye that responded, through visible colour changes to the formation of basic volatile amines in the package headspace. The response was also found to correlate with total viable count and Pseudomonas growth. Using the same principle other authors designed a variety of freshness indicators for fish and poultry meat based on the $\mathrm{pH}$ increase produced as a result of TVBN accumulation (Kuswandi, Jayus, Larasati, Abdullah, \& Heng, 2012a; Kuswandi, Jayus, Oktaviana, Abdullah, \& Heng, 2014; Kuswandi et al., 2012b). The authors developed indicators based on a polyaniline film, a methyl red/cellulose membrane, and a curcumin/bacterial cellulose membrane that responded through a visible colour change to a variety of basic volatile amines released during fish spoilage.

All the reported indicators are based on the detection of a single compound or parameter, and they have some limitations such as lack of specificity with the risk of offering false positives or false negatives (Kerry et al., 2006; Kuswandi et al., 2011; Nopwinyuwong, Trevanich, \& Suppakul, 2010). Therefore, a promising and potent approach to be applied in complex matrices such as meat is the use of colorimetric sensor arrays able to offer 
information through suitable colour modulations (Salinas et al., 2014). Salinas et al. (2014) developed an optoelectronic nose composed of seven sensing materials prepared by the incorporation of $\mathrm{pH}$ indicators and chromogenic reagents with different chemical recognition properties to monitor the quality of pork sausages. According to the authors, the array was able to monitor the spoilage process of fresh sausages.

A great advance on the application of intelligent systems to monitor food freshness is the development of biosensors able to detect target metabolites produced during food spoilage. Pospiskova, Safarik, Sebela, and Kuncova (2012) developed a biosensor for the detection of biogenic amines, basic nitrogen compounds formed mainly by decarboxylation of amino acid or by amination and transamination of aldehydes and ketones generated in the course of microbial metabolism. The detection of the levels of glucose as an indicator of meat spoilage was possible with the development of a glucose sensor using a gold electrode modified using L-cysteine and a nanogold solution, coated with a polyglutamate-glucose oxidase complex dropped on the modified electrode (Umuhumuza \& Sun, 2011). Several authors have developed biosensors able to detect the formation of xanthine, a product of adenine nucleotide degradation in animal tissues that can be used as freshness indicators (Arvanitoyannis \& Stratakos, 2012). The construction of amperometric xanthine biosensors based on immobilization of xanthine oxidase onto electrodes made of a variety of materials such as platinum, silver and pencil graphite electrodes has been described in the bibliography (Devi, Batra, Lata, Yadav, \& Pundir, 2013; Devi, Yadav, Nehra, Yadav, \& Pundir, 2013; Dolmacı, Çete, Arslan, \& Yaşar, 2012).

The integration of biosensors to food packaging systems is still a big challenge. A successful example of biosensors integrated to packaging materials are those constructed with molecularly imprinted polymer biosensors. Molecular imprinting technology is a promising technique for creating recognition elements for selected analyte molecules. The analyte molecules are incorporated into a pre-polymeric mixture and allowed to form bonds with the pre-polymer. The mixture is then polymerized with the analyte molecules in place. Once the polymer has formed, the analyte molecules are removed, leaving behind cavities with the analyte molecule's shape. In this way, a particular molecule can be identified since the shape of the cavity is specific to the molecule modelled. This invention is an inexpensive polymer material that indicates meat spoilage through a colour change (Johns Hopkins University Applied Physics Laboratory, 2014). Kelly, Murray, and Uy (2005) patented a molecularly imprinted polymeric food spoilage sensor that comprises a polymer containing a polyazamacrocyclic transition metal complex. The complex selectively binds biogenic amines, such as cadaverine, putrescine and histamine, which are released by food spoilage microorganisms. The polymer undergoes a detectable colour change upon exposure to biogenic amine, thus indicating that food spoilage has probably occurred. The polymer is easily incorporated in common food containers and can be employed in fibre optic detection devices.

As we have seen in the previous section a number of prototypes have been produced by packaging and biotechnology companies, however freshness indicators haven't been successfully implemented in the market. The main limitation is that food processors are not willing to risk their image by placing in the market a packaging system that could evidence one of their products as not fresh. Therefore, developed freshness indicators should be attractive to food processors to be implemented in the market. The integration of food sensors to RFID systems would be a solution that would benefit all the food chain actors as it would assure that no spoiled or contaminated product would arrive to the consumer with the consequent benefit for the production, distribution and retail sectors.

\subsection{Radiofrequency identification (RFID)}

Commercial applications of RFID systems have integrated time-temperature indicators, as previously described. Further research is being done in order to integrate RFID systems with 
indicators and sensors that are able to monitor the quality of muscle based food products during its shelf life. A flexible $\mathrm{pH}$ sensor embedded in a batteryless radiofrequency transponder was developed by Huang, Deb, Seo, Rao, Chiao and Chiao (2012). The wireless pH sensing system was tested for in situ monitoring of the spoilage processes in fish products continuously for over $18 \mathrm{~h}$. However, the authors could not prove the feasibility of monitoring fish spoilage by wireless pH-monitoring (Huang et al., 2012). Martínez-Olmos et al. (2013) invented a RFID tag with an optical oxygen indicator consisting of a platinum octaethylporphyrin membrane and a full electronic system for RFID communication, all printed on a flexible substrate. The system resulted perfectly suitable for its use in MAP where the oxygen concentration is reduced below $2 \%$, presenting a limit of detection of $40 \mathrm{ppm}$ and a resolution as low as $0.1 \mathrm{ppm}$ of $\mathrm{O}_{2}$ reached with a low power consumption of $3.55 \mathrm{~mA}$. Sen, Hyun, Kim, Shin, and Eom (2013) successfully estimated the freshness of pork using a monitoring system consisting of an RFID tag, a temperature sensor, a gas sensor, a reader, and

server. Finally, smart radiofrequency labels with sensors able to measure temperature, humidity and the presence of volatile amine compounds were used by Smits et al. (2012) to estimate the freshness of cod fish.

\section{Market share and perspectives of active and intelligent packaging systems}

The global market for advanced packaging systems that includes active, controlled, intelligent packaging, and advanced packaging components was at \$31.4 billion in 2011 and $\$ 33.3$ billion in 2012. The market growth looks promising and the overall market value for 2017 is projected to be nearly $\$ 44.3$ billion, after increasing at a compound annual growth rate (CAGR) of 5.8\% (BCC Research, 2013a). In 2011, the market was dominated by controlled packaging. Active packaging was next in market share with nearly $\$ 8.8$ billion in sales, and is expected to grow up to $\$ 11.9$ billion in 2017. The intelligent packaging sales were nearly $\$ 3.8$ billion in 2011 and could approach \$5.3 billion in 2017 (BCC Research, 2013b).

Oxygen scavengers and moisture absorbers are by far the most commercially important sub-categories of active packaging (Day, 2008). Gas scavengers were the leading active packaging product type in 2012 in the USA (Market Research, 2014). According to Freedonia Group Inc., gas scavenger demand will climb at a fast rate due to expanded applications for oxygen scavengers. Additionally, active packaging growth will be stimulated by solid prospects for microwave susceptor packaging and by solid increases for self-venting packaging. Rapid growth from a low base is anticipated for antimicrobial packaging, encouraged by technological developments. However, cost and performance factors will still be a limitation (Market Research, 2014). The company predicts strong gains for timetemperature indicator labels, based on growing cost competitiveness together with the increased presence of temperature-sensitive drugs and the heightened focus on food safety through the supply chain.

The need to reduce food waste and to optimise the use of raw materials would favour the implementation of packaging technologies such as active and intelligent packaging. These technologies are designed to satisfy the increasing demand for food safety and longer shelf lives, to contribute to a better stock management, and to clearly favour brand differentiation. Therefore, active and intelligent packaging support higher food quality, reduced waste and complaints from retailers and consumers, and improved overall efficiency. These are the main reasons why active and intelligent packaging systems are expected to play a key role in perishable food sectors such as the muscle based food industry. However, technical limitations and the high cost associated with these technologies have been the main constraints to a more significant implementation of active and intelligent packaging in the meat and fish industries marketing products with a limited added value.

The big challenge for active packaging is to develop active materials able to preserve their original mechanical and barrier properties. The addition of purer active substances rather 
than the use of non-purified extracts or the use of active compounds in the form of nanoparticles would reduce the amount of required active substance and would therefore contribute to preserve the original properties of the material. It is expected that commercial applications of antimicrobial and antioxidant materials will grow in order to offer increased safety and extended shelf life. The use of active compounds derived from natural resources is also expected to continue growing as well as the incorporation of biodegradable packaging materials as carrier polymers.

Intelligent packaging applications in the meat industry are still limited. It could be expected that the continuous advances in biotechnology, analytical chemistry, microelectronics, and materials science will contribute to the development of new intelligent packaging solutions. However, the main constraints are still the price and the integration of the intelligent concepts to the packaging material. A high potential for intelligent packaging is the integration of biosensors to RFID systems to inform and communicate real time information about the state of the product leading to improved safety, quality, and stock management, and reduce losses. Developments to better integrate intelligent systems in the packaging material are essential for cost reduction. Advances in printed electronics used to create electrical devices on a wide range of different substrates by depositing layers of conductive inks, will contribute to the integration of intelligent systems to the packaging materials. The advantages of printed structures include low price and disposability. Advances in ink technology such as the use of graphene inks with a unique combination of properties including mechanical flexibility, high electrical conductivity, and chemical stability, make it ideal for next-generation electronics (AIPIA, 2013c). Carbon nanotubes coated with inherently conductive polymers by chemical polymerisation methods offer new opportunities for tailoring material electrical properties. With proper mixing and suitable matrix materials these new materials have enhanced properties due to its electron transfer ability (Ritschkoff, Smolander, $\&$ Paajanen, 2007). Continuous research and development and cost reductions will contribute to a wider adoption of this technology in the meat industry in the future. 


\section{References}

3M. (2014). 3M $3 \mathrm{M}^{\mathrm{TM}} \quad$ MonitorMark $^{\mathrm{TM}}$ Time Temperature Indicators. http://solutions.3m.com/wps/portal/3M/en US/Microbiology/FoodSafety/productinformation/productcatalog/?PC Z7 RJH9U523003DC523023S523007P5230920523003087000000 nid=NFNLL 87000005 PG87000088beX87000002JZNTZSLTgl.Last accessed: 02/03/2014.

Abdollahi, M., Rezaei, M., \& Farzi, G. (2012). Improvement of active chitosan film properties with rosemary essential oil for food packaging. International Journal of Food Science and Technology, 47(4), 847-853.

Agion. (2007). MicrobeGuard's Food Touch ${ }^{\circledR}$ Paper Liners Now Feature Agion ${ }^{\circledR}$ Antimicrobial. http://www.agion-tech.com/NewsAndEvents.aspx?id=206. Last accessed: 15/01/2014.

Ahvenainen, R. (2003). Active and intelligent packaging: an introduction. In R. Ahvenainen (Ed.), Novel food packaging techniques (pp. 5-21). Cambridge, UK: Woodhead Publishing Ltd.

AIPIA. (2013a). Co-operation creates rigid oxygen absorber pack. http://www.aipworldcongress.org/news 220 cooperation-creates-rigid-oxygen-absorber-pack.php. Last accessed: 21/03/2014.

AIPIA. (2013b). Glass-clear PET with Oxygen Scavenging. http://www.aipia.info/news 250 glassclear-pet-with-oxygen-scavenging.php. Last accessed: 07/02/2014.

AIPIA. (2013c). Improved graphene inks for inkjet application. http://www.aipworldcongress.org/news 218 improved-graphene-inks-for-inkjet-application.php. Last accessed: 04/02/2014.

Akbar, A., \& Anal, A. K. (2014). Zinc oxide nanoparticles loaded active packaging, a challenge study against Salmonella typhimurium and Staphylococcus aureus in ready-to-eat poultry meat. Food Control, 38(0), 88-95.

ALBIS. (2014). SHELFPLUS ${ }^{\circledast} \mathrm{O}_{2}-$ a fresh solution to active packaging. http://www.albis.com/en/products-solutions/standard-plastic/shelfplus/. Last accessed: 21/03/2014.

Altieri, C., Sinigaglia, M., Corbo, M. R., Buonocore, G. G., Falcone, P., \& Del Nobile, M. A. (2004). Use of entrapped microorganisms as biological oxygen scavengers in food packaging applications. Lebensmittel-Wissenschaft und Technology, 37, 9-15.

Ananou, S., Garriga, M., Hugas, M., Maqueda, M., Martínez-Bueno, M., Gálvez, A., \& Valdivia, E. (2005). Control of Listeria monocytogenes in model sausages by enterocin AS-48. International Journal of Food Microbiology, 103, 179-190.

Anthierens, T., Ragaert, P., Verbrugghe, S., Ouchchen, A., De Geest, B. G., Noseda, B., Mertens, J., Beladjal, L., De Cuyper, D., Dierickx, W., Du Prez, F., \& Devlieghere, F. (2011). Use of endospore-forming bacteria as an active oxygen scavenger in plastic packaging materials. Innovative Food Science \& Emerging Technologies, 12(4), 594-599.

Appendini, P., \& Hotchkiss, J. H. (2002). Review of antimicrobial food packaging. Innovative Food Science \& Emerging Technologies, 3, 113-126.

Artibal. (2014). Antioxidant packaging. http://www.artibal.com/index.php/en/research-ainnovation/active/56. Last accessed: 10/03/2014.

Arvanitoyannis, I. S., \& Stratakos, A. C. (2012). Application of Modified Atmosphere Packaging and Active/Smart Technologies to Red Meat and Poultry: A Review. Food and Bioprocess Technology, 5(5), 1423-1446.

Avery Dennison. (2011). Roll-to-Roll Processing. http://www.averydennison.com/en/home/technologies/core-capabilities.html. Last accessed: 03/04/2014. 
Aymerich, T., Garriga, M., Jofré, A., Martín, B., \& Monfort, J. M. (2006). The use of bacteriocins against Meat-borne pathogens. In L. M. L. Nollet \& F. Toldrà (Eds.), Advanced technologies for meat processing. New York: Marcel Dekker, Inc.

Aymerich, T., Garriga, M., Ylla, J., Vallier, J., Monfort, J. M., \& Hugas, M. (2000). Application of Enterocins as biopreservatives against Listeria innocua in meat products. Journal of Food Protection, 63(6), 721-726.

Aymerich, T., Holo, H., Havarstein, L. S., Hugas, M., Garriga, M., \& Nes, I. F. (1996). Biochemical and genetic characterization of enterocin A from Enterococcus faecium, a new antilisterial bacteriocin in the pediocin family of bacteriocins. Applied and Environmental Microbiology, $62,1676-1682$.

Barbosa-Pereira, L., Aurrekoetxea, G. P., Angulo, I., Paseiro-Losada, P., \& Cruz, J. M. (2014). Development of new active packaging films coated with natural phenolic compounds to improve the oxidative stability of beef. Meat Science, 97(2), 249-254.

Basch, C., Jagus, R., \& Flores, S. (2013). Physical and Antimicrobial Properties of Tapioca StarchHPMC Edible Films Incorporated with Nisin and/or Potassium Sorbate. Food and Bioprocess Technology, 6(9), 2419-2428.

Bastarrachea, L., Dhawan, S., \& Sablani, S. (2011). Engineering Properties of Polymeric-Based Antimicrobial Films for Food Packaging: A Review. Food Engineering Reviews, 1-15.

BCC Research. (2013a). Active, Controlled, and Intelligent Packaging for Foods and Beverages. http://www.bccresearch.com/market-research/food-and-beverage/food-beveragepackaging-fod038c.html. May 2013. Last accessed: 01/03/2014.

BCC Research. (2013b). The advanced packaging solutions market value for 2017 is projected to be nearly $\$ 44.3$ billion. http://www.bccresearch.com/pressroom/fod/advancedpackaging-solutions-market-value-projected-nearly-\$44.43-billion-2017. April 2013. Last accessed: 01/03/2014.

Bemis-Curwood. (2014). FreshCase ${ }^{\circledR}$ active vacuum packaging. http://curwoodinnovates.com/freshcase/. Last accessed: 20/03/2014.

Bioka. (2014). New natural oxygen absorbing technology for food quality preservation. http://www.bioka.fi/. Last accessed: 21/03/2014.

Blanco-Fernandez, B., Isabel Rial-Hermida, M., Alvarez-Lorenzo, C., \& Concheiro, A. (2013). Edible chitosan/acetylated monoglyceride films for prolonged release of vitamin $E$ and antioxidant activity. Journal of Applied Polymer Science, 129(2), 626-635.

Blanco Massani, M., Molina, V., Sanchez, M., Renaud, V., Eisenberg, P., \& Vignolo, G. (2014). Active polymers containing Lactobacillus curvatus CRL705 bacteriocins: Effectiveness assessment in Wieners. International Journal of Food Microbiology, 178(0), 7-12.

Bohrer, T. H. (2009). Shielding and field modification - thick metal films. In M. W. Lorence \& P. S. Pesheck (Eds.), Development of packaging and products for use in microwave ovens (pp. 236-266). Cambridge, UK: Woodhead Publishing Limited.

Bolumar, T., Andersen, M. L., \& Orlien, V. (2011). Antioxidant active packaging for chicken meat processed by high pressure treatment. Food Chemistry, 129(4), 1406-1412.

Boscher, N. D., Bohn, T., Heier, P., Moisy, F., Untereiner, B., Heinze, K., \& Choquet, P. (2014). Optical sensing responses of $\mathrm{Cr}{ }^{\prime \prime \prime} \mathrm{Cl}(\mathrm{TPP})\left(\mathrm{H}_{2} \mathrm{O}\right)$-based coatings obtained by an atmospheric pressure plasma method - Application to the detection of volatile amines. Sensors and Actuators B: Chemical, 191(0), 553-560.

Brizio, A. P. D. R., \& Prentice, C. (2014). Use of smart photochromic indicator for dynamic monitoring of the shelf life of chilled chicken based products. Meat Science, 96(3), 12191226.

Brody, A. L., Bugusu, B., Han, J. H., Sand, C. K., \& McHugh, T. H. (2008). Innovative food packaging solutions. Journal of Food Science, 73(8), R107-R116.

Brody, A. L., Strupinsky, E. R., \& Kline, L. R. (2001). Active packaging for food applications. Lancaster, PA, USA: Technomic Publishing Company, Inc. 
Busolo, M. A., \& Lagaron, J. M. (2012). Oxygen scavenging polyolefin nanocomposite films containing an iron modified kaolinite of interest in active food packaging applications. Innovative Food Science \& Emerging Technologies, 16, 211-217.

Byun, Y., Bae, H. J., \& Whiteside, S. (2012). Active warm-water fish gelatin film containing oxygen scavenging system. Food Hydrocolloids, 27(1), 250-255.

Byun, Y., Darby, D., Cooksey, K., Dawson, P., \& Whiteside, S. (2011). Development of oxygen scavenging system containing a natural free radical scavenger and a transition metal. Food Chemistry, 124(2), 615-619.

Byun, Y., Kim, Y. T., \& Whiteside, S. (2010). Characterization of an antioxidant polylactic acid (PLA) film prepared with $\alpha$-tocopherol, BHT and polyethylene glycol using film cast extruder. Journal of Food Engineering, 100(2), 239-244.

Byun, Y., \& Whiteside, S. (2012). Ascorbyl palmitate-beta-cyclodextrin inclusion complex as an oxygen scavenging microparticle. Carbohydrate Polymers, 87(3), 2114-2119.

$\begin{array}{lllll}\text { CAEN RFID. (2014). CAEN RFID easy2log@ } & \text { RT0005. }\end{array}$ http://www.caenrfid.it/en/CaenProd.jsp?mypage=3\&parent=65\&idmod=780. Last accessed: $14 / 02 / 2014$

Calatayud, M., López-de-Dicastillo, C., López-Carballo, G., Vélez, D., Hernández Muñoz, P., \& Gavara, R. (2013). Active films based on cocoa extract with antioxidant, antimicrobial and biological applications. Food Chemistry, 139(1-4), 51-58.

Camo, J., Antonio Beltrán, J., \& Roncalés, P. (2008). Extension of the display life of lamb with an antioxidant active packaging. Meat Science, 80(4), 1086-1091.

Camo, J., Lorés, A., Djenane, D., Beltrán, J. A., \& Roncalés, P. (2011). Display life of beef packaged with an antioxidant active film as a function of the concentration of oregano extract. Meat Science, 88(1), 174-178.

Cerisuelo, J. P., Bermúdez, J. M., Aucejo, S., Catalá, R. n., Gavara, R., \& HernÃindez-Muñoz, P. (2013). Describing and modeling the release of an antimicrobial agent from an active PP/EVOH/PP package for salmon. Journal of Food Engineering, 116(2), 352-361.

Cha, D. S., \& Chinnan, M. S. (2004). Biopolymer-based antimicrobial packaging: a review. Critical Reviews in Food Science and Nutrition, 44(4), 223-237.

Cheah, P. B., \& Ledward, D. A. (1996). High pressure effects on lipid oxidation in minced pork. Meat Science, 43(2), 123-134.

Chen, J., \& Brody, A. L. (2013). Use of active packaging structures to control the microbial quality of a ready-to-eat meat product. Food Control, 30(1), 306-310.

Clariant. (2013). Oxygen protection for packaged foods. http://www.desiccants.clariant.com/oxygen-absorption-protection-for-packagedfood.html. Last accessed: 07/02/0214.

$\mathrm{CO}_{2}$ Technologies. (2014). Solutions and Applications for Seafood. http://www.co2technologies.com/seafood products.html. Last accessed: 04/03/2014.

Coma, V. (2008). Bioactive packaging technologies for extended shelf life of meat-based products. Meat Science, 78(1-2), 90-103.

Concha-Meyer, A., Schobitz, R., Brito, C., \& Fuentes, R. (2011). Lactic acid bacteria in an alginate film inhibit Listeria monocytogenes growth on smoked salmon. Food Control, 22(3/4), 485-489.

Corrales, M., Fernández, A., \& Han, J. H. (2014). Antimicrobial packaging systems. In J. H. Han (Ed.), Innovations in food packaging (Second ed., pp. 133-170). San Diego, USA: Academic Press.

Corrales, M., Han, J. H., \& Tauscher, B. (2009). Antimicrobial properties of grape seed extracts and their effectiveness after incorporation into pea starch films. International Journal of Food Science \& Technology, 44(2), 425-433.

Craemer. (2014). New RFID supported fish box enables seamless tracking \& tracing. http://www.craemer.com/en/service-portal/news/detail/article/craemer-group-presentsproduct-innovation-for-the-fishing-industry/. Last accessed: 12/02/2014. 
CSL. (2013). CS8304 Cold Chain Temperature Logging Tag. http://www.convergence.com.hk/products/rfid/rfid-tags/cs8304/. Last accessed: $11 / 02 / 2014$.

Datta, S., Janes, M. E., Xue, Q. G., Losso, J., \& La Peyre, J. F. (2008). Control of Listeria monocytogenes and Salmonella anatum on the Surface of Smoked Salmon Coated with Calcium Alginate Coating containing Oyster Lysozyme and Nisin. Journal of Food Science, 73(2), M67-M71.

Day, B. P. F. (2008). Active packaging of food. In J. P. Kerry \& P. Butler (Eds.), Smart packaging technologies for fast moving consumer goods (pp. 1-18). West Sussex, UK: John Wiley \& Sons, Ltd.

de Azeredo, H. M. C. (2009). Nanocomposites for food packaging applications. Food Research International, 42(9), 1240-1253.

Devi, R., Batra, B., Lata, S., Yadav, S., \& Pundir, C. S. (2013). A method for determination of xanthine in meat by amperometric biosensor based on silver nanoparticles/cysteine modified Au electrode. Process Biochemistry, 48(2), 242-249.

Devi, R., Yadav, S., Nehra, R., Yadav, S., \& Pundir, C. S. (2013). Electrochemical biosensor based on gold coated iron nanoparticles/chitosan composite bound xanthine oxidase for detection of xanthine in fish meat. Journal of Food Engineering, 115(2), 207-214.

Dias, M. V., Soares, N. F. F., Borges, S. V., de Sousa, M. M., Nunes, C. A., de Oliveira, I. R. N., \& Medeiros, E. A. A. (2013). Use of allyl isothiocyanate and carbon nanotubes in an antimicrobial film to package shredded, cooked chicken meat. Food Chemistry, 141(3), 3160-3166.

Dolmacı, N., Çete, S., Arslan, F., \& Yaşar, A. (2012). An amperometric biosensor for fish freshness detection from xanthine oxidase immobilized in polypyrrole-polyvinylsulphonate film. Artificial Cells, Nanomedicine, and Biotechnology, 40(4), 275-279.

DSM. (2007). DSM invests in food freshness device company. https://www.dsm.com/corporate/media/informationcenter-news/2007/2008/2051-2007DSM-invests-in-food-freshness-device-company.html. Last accessed: 07/03/2014.

EFSA. (2013). Scientific Opinion on the safety evaluation of a time-temperature indicator system, based on Carnobacterium maltaromaticum and acid fuchsin for use in food contact materials. EFSA Journal, 11(7), 3307.

EFSA. (2014). Scientific Opinion on the safety assessment of the active substances, palladium metal and hydrogen gas, for use in active food contact materials. EFSA Journal, 12(2), 35583566.

Ellouze, M., \& Augustin, J. C. (2010). Applicability of biological time temperature integrators as quality and safety indicators for meat products. International Journal of Food Microbiology, 138(1-2), 119-129.

Ellouze, M., Gauchi, J. P., \& Augustin, J. C. (2011). Use of global sensitivity analysis in quantitative microbial risk assessment: Application to the evaluation of a biological time temperature integrator as a quality and safety indicator for cold smoked salmon. Food Microbiology, 28(4), 755-769.

Emco Packaging. (2013). Oxygen Indicator Labels. http://www.emcopackaging.com/index.php/products/oxygen-indicator-labels. Last accessed: 15/03/2014.

Emiroglu, Z. K., Yemis, G. P., Coskun, B. K., \& Candogan, K. (2010). Antimicrobial activity of soy edible films incorporated with thyme and oregano essential oils on fresh ground beef patties. Meat Science, 86(2), 283-288.

Ercolini, D., Ferrocino, I., La Storia, A., Mauriello, G., Gigli, S., Masi, P., \& Villani, F. (2010). Development of spoilage microbiota in beef stored in nisin activated packaging. Food Microbiology, 27(1), 137-143. 
Etienne, M. (2005). SEAFOODplus- Methods for chemical quality assessment: Volatile amines as criteria for chemical quality assessment. In: Ifremer, Nantes, France. http://archimer.ifremer.fr/doc/2005/rapport-6486.pdf. Last accessed: 04/01/2014.

European Commission. (2009). Commission Regulation (EC) No 450/2009 of 29 May 2009 on active and intelligent materials and articles intended to come into contact with food Official Journal of the European Union, L 135, 1-11.

European Commission. (2011). Provisional list of additives for use in food contact materials. http://ec.europa.eu/food/food/chemicalsafety/foodcontact/docs/080410 provisional list 080417 211009.pdf . Last accessed: 15/01/082014.

European Commission. (2012a). How to avoid food wastage: strategies for a more efficient food chain in the EU. Procedure file 2011/2175(INI), http://www.europarl.europa.eu/sides/getDoc.do?pubRef=-//EP//NONSGML+REPORT+A72011-0430+2010+DOC+PDF+V2010//EN.

European Commission. (2012b). Regulation (EU) No 528/2012 of the European Parliament and of the Council of 22 May 2012 concerning the making available on the market and use of biocidal products. Official Journal of the European Union, L 167, 1-123

Fernández, A., Picouet, P., \& Lloret, E. (2010). Reduction of the Spoilage-Related Microflora in Absorbent Pads by Silver Nanotechnology during Modified Atmosphere Packaging of Beef Meat. Journal of Food Protection, 73(12), 2263-2269.

Ferrari, M. C., Carranza, S., Bonnecaze, R. T., Tung, K. K., Freeman, B. D., \& Paul, D. R. (2009). Modeling of oxygen scavenging for improved barrier behavior: Blend films. Journal of Membrane Science, 329(1-2), 183-192.

Ferrocino, I., La Storia, A., Torrieri, E., Musso, S. S., Mauriello, G., Villani, F., \& Ercolini, D. (2013). Antimicrobial Packaging To Retard the Growth of Spoilage Bacteria and To Reduce the Release of Volatile Metabolites in Meat Stored under Vacuum at $1^{\circ} \mathrm{C}$. Journal of Food Protection, 76(1), 52-58.

Floros, J. D., Dock, L. L., \& Han, J. H. (1997). Active packaging technologies and applications. Food Cosmetics and Drug Packaging, 20, 10-17.

Freshpoint. (2011a). BestBy. http://www.freshpoint-tti.com/product/BestBy.aspx. Last accessed: 15/03/2014.

Freshpoint. (2011b). Oxygen Sensors Technology. http://www.freshpointtti.com/technology/default.aspx. Last accessed: 15/03/2014.

Freshpoint. (2011c). Time Temperature Indicator Consumer Brand. http://www.freshpointtti.com/links/default.aspx. Last accessed: 02/03/2014.

FSANZ (Food Standards Australia New Zealand). (2007). Final assessment report application A565 use of nisin in processed meat products In: Food Standards Australia New Zealand.

FSIS (Food Safety and Inspection Service). (2002). FSIS Directive 7120.1: Safe and Suitable Ingredients Used in the Production of Meat and Poultry Products. In FSIS/USDA (Ed.), FSIS Directive 7120.1.

Galagan, Y., \& Su, W. F. (2008). Fadable ink for time-temperature control of food freshness: Novel new time-temperature indicator. Food Research International, 41(6), 653-657.

Galotto, M. J., Valenzuela, X., Rodriguez, F., Bruna, J., \& Guarda, A. (2012). Evaluation of the Effectiveness of a New Antimicrobial Active Packaging for Fresh Atlantic Salmon (Salmo Salar L.) Shelf Life. Packaging Technology and Science, 25(6), 363-372.

Giannakourou, M. C., Koutsoumanis, K., Nychas, G. J. E., \& Taoukis, P. S. (2005). Field evaluation of the application of time temperature integrators for monitoring fish quality in the chill chain. International Journal of Food Microbiology, 102(3), 323-336.

Giménez, B., Gómez-Guillén, M. C., Pérez-Mateos, M., Montero, P., \& Márquez-Ruiz, G. (2011). Evaluation of lipid oxidation in horse mackerel patties covered with borage-containing film during frozen storage. Food Chemistry, 124(4), 1393-1403.

Guillory, M., \& Standhardt, G. (2012). NVC World Review on Supply Chain Applications of RFID and Sensors in Packaging. http://www.nvc.nl/nl/pasteur-sensor-enabled- 
rfid/files content/NVC\%20World\%20Review\%20on\%20Supply\%20Chain\%20Applications\%2 0of\%20RFID\%20and\%20Sensors\%20in\%20Packaging.pdf. Last accessed: 27/02/2014.

Han, J. H. (2000). Antimicrobial food packaging. Food Technology, 54(3), 56-65.

Han, J. H. (2014). A review of food packaging technologies and innovations. In J. H. Han (Ed.), Innovations in food packaging (pp. 3-12). San Diego, USA: Academic Press.

Han, J. Y., Kim, M. J., Shim, S. D., \& Lee, S. J. (2012). Application of fuzzy reasoning to prediction of beef sirloin quality using time temperature integrators (TTIs). Food Control, 24(1-2), 148153.

Hansen, A. A., Morkore, T., Rudi, K., Olsen, E., \& Eie, T. (2007). Quality changes during refrigerated storage of MA-packaged pre-rigor fillets of farmed Atlantic cod (Gadus morhua L.) using traditional MAP, $\mathrm{CO}_{2}$ emitter, and vacuum. Journal of Food Science, 72(9), M423M430.

Hansen, A. A., Morkore, T., Rudi, K., Rodbotten, M., Bjerke, F., \& Eie, T. (2009). Quality Changes of Prerigor Filleted Atlantic Salmon (Salmo salar L.) Packaged in Modified Atmosphere Using $\mathrm{CO}_{2}$ Emitter, Traditional MAP, and Vacuum. Journal of Food Science, 74(6), M242-M249.

Hereu, A., Bover-Cid, S., Garriga, M., \& Aymerich, T. (2012). High hydrostatic pressure and biopreservation of dry-cured ham to meet the Food Safety Objectives for Listeria monocytogenes. International Journal of Food Microbiology, 154(3), 107-112.

Higueras, L., López-Carballo, G., Hernández-Muñoz, P., Gavara, R., \& Rollini, M. (2013). Development of a novel antimicrobial film based on chitosan with LAE (ethyl- $\mathrm{N}^{\alpha}$ dodecanoyl-L-arginate) and its application to fresh chicken. International Journal of Food Microbiology, 165(3), 339-345.

Holck, A. L., Pettersen, M. K., Moen, M. H., \& Sørheim, O. (2014). Prolonged shelf life and reduced drip loss of chicken filets by the use of carbon dioxide emitters and modified atmosphere packaging. Journal of Food Protection, 7, 1052-1240.

Huang, W. D., Deb, S., Seo, Y. S., Rao, S., Chiao, M., \& Chiao, J. (2012). A Passive RadioFrequency $\mathrm{pH}$-Sensing Tag for Wireless Food-Quality Monitoring. Sensors Journal, IEEE, 12(3), 487,495.

Hurme, E. (2003). Detecting leaks in modified atmosphere packgaging. In R. Ahvenainen (Ed.), Novel food packaging techniques (pp. 276-286). Cambridge, UK: Woodhead Publishing Ltd.

Infante, M., Pinazo, A., \& Seguer, J. (1997). Non-conventional surfactants from amino acids and glycolipids: Structure, preparation and properties. Colloids and Surfaces A: Physicochemical and Engineering Aspects, 123-124, 49-70.

Insignia Technologies. (2014). Novas: Embedded Label. http://insignia.mtcserver11.com/portfolio-view/novas-embedded-label/. Last accessed 15/03/2014.

Jamshidian, M., Tehrany, E. A., Imran, M., Akhtar, M. J., Cleymand, F., \& Desobry, S. (2012). Structural, mechanical and barrier properties of active PLA-antioxidant films. Journal of Food Engineering, 110(3), 380-389.

Jang, N. Y., \& Won, K. (2014). New pressure-activated compartmented oxygen indicator for intelligent food packaging. International Journal of Food Science \& Technology, 49(2), 650654.

Järnström, L., Johansson, K., Jönsson, L. J., Winestrand, S., Chatterjee, R., Nielsen, T., Antvorskov, H., Rotabakk, B. T., Guðmundsson, M., Kuusipalo, J., Kotkamo, S., Christophliemk, H., Weber, A., Walles, H., Thude, S., Engl, J., Herz, M., \& Forsgren, G. (2013). ENZYCOAT II - Enzymes embedded in barrier coatings for active packaging. In N. Innovation (Ed.), Nordic Innovation Publication 203 (pp. 1-96). Oslo 2013.

Jofré, A., Aymerich, T., \& Garriga, M. (2008). Assessment of the effectiveness of antimicrobial packaging combined with high pressure to control Salmonella sp. in cooked ham. Food Control, 19(6), 634-638. 
Jofré, A., Garriga, M., \& Aymerich, T. (2007). Inhibition of Listeria monocytogenes in cooked ham through active packaging with natural antimicrobials and high-pressure processing. Journal of Food Protection, 70(11), 2498-2502.

Johns Hopkins University Applied Physics Laboratory. (2014). A Colorimetric Sensor of Food Spoilage Based on a Molecularly Imprinted Polymer. http://www.jhuapl.edu/ott/technologies/technology/articles/P01491.asp. Last accessed: 18/03/02014.

Jouki, M., Yazdi, F. T., Mortazavi, S. A., Koocheki, A., \& Khazaei, N. (2014). Effect of quince seed mucilage edible films incorporated with oregano or thyme essential oil on shelf life extension of refrigerated rainbow trout fillets. International Journal of Food Microbiology, 174(0), 88-97.

Juck, G., Neetoo, H., \& Chen, H. (2010). Application of an active alginate coating to control the growth of Listeria monocytogenes on poached and deli turkey products. International Journal of Food Microbiology, 142(3), 302-308.

Jung, J., Puligundla, P., \& Ko, S. (2012). Proof-of-concept study of chitosan-based carbon dioxide indicator for food packaging applications. Food Chemistry, 135(4), 2170-2174.

Keep-it Technologies. (2014). Why Keep-it? , http://keep-it.no/en/why-keep-it/. Last accessed 02/03/2014.

Kelly, C. A., Murray, G. M., \& Uy, O. M. (2005). Method of making a polymeric food spoilage sensor (US $6924147 \quad$ B2). In: Google Patents. http://www.google.com.br/patents/US6924147.

Kerry, J. P. (2014). New packaging technologies, materials and formats for fast-moving consumer products. In J. H. Han (Ed.), Innovations in food packaging (Second ed., pp. 549584). San Diego, USA: Academic Press.

Kerry, J. P., O'Grady, M. N., \& Hogan, S. A. (2006). Past, current and potential utilisation of active and intelligient packaging systems for meat and muscle-based products: A review. Meat Science, 74, 113-130.

Kim, E., Choi, D. Y., Kim, H. C., Kim, K., \& Lee, S. J. (2013). Calibrations between the variables of microbial TTI response and ground pork qualities. Meat Science, 95(2), 362-367.

Kim, Y.-M., Paik, H.-D., \& Lee, D.-S. (2002). Shelf-life characteristics of fresh oysters and ground beef as affected by bacteriocin-coated plastic packaging film. In (Vol. 82, pp. 998-1002): John Wiley \& Sons, Ltd.

Kuswandi, B., Jayus, Larasati, T. S., Abdullah, A., \& Heng, L. Y. (2012a). Real-Time Monitoring of Shrimp Spoilage Using On-Package Sticker Sensor Based on Natural Dye of Curcumin. Food Analytical Methods, 5(4), 881-889.

Kuswandi, B., Jayus, Oktaviana, R., Abdullah, A., \& Heng, L. Y. (2014). A Novel On-Package Sticker Sensor Based on Methyl Red for Real-Time Monitoring of Broiler Chicken Cut Freshness. Packaging Technology and Science, 27(1), 69-81.

Kuswandi, B., Jayus, Restyana, A., Abdullah, A., Heng, L. Y., \& Ahmad, M. (2012b). A novel colorimetric food package label for fish spoilage based on polyaniline film. Food Control, 25(1), 184-189.

Kuswandi, B., Wicaksono, Y., Abdullah, A., Jayus, Heng, L. Y., \& Ahmad, M. (2011). Smart packaging: sensors for monitoring of food quality and safety. Sensing and Instrumentation for Food Quality and Safety, 5, 137-146.

Kerry, J. P., O'Grady, M. N., \& Hogan, S. A. (2006). Past, current and potential utilisation of active and intelligient packaging systems for meat and muscle-based products: A review. Meat Science, 74, 113-130.

Kyodo Printing. (2013). OxyCatch ${ }^{\mathrm{TM}}$. http://landi.kyodoprinting.co.jp/cn/oxycatch.html. Last accessed: 07/02/2013.

La Storia, A., Mauriello, G., Villani, F., \& Ercolini, D. (2013). Coating-Activation and Antimicrobial Efficacy of Different Polyethylene Films with a Nisin-Based Solution. Food and Bioprocess Technology, 6, 2770-2779. 
Laboratories STANDA. (2014a). ATCO ${ }^{\circ}$ http://www.standa-fr.com/eng/laboratoiresstanda/atco/. Last accessed: 04/02/2014.

Laboratories STANDA. (2014b). SANICO ${ }^{\circledR}$ is our range of antifungal coatings for the agro-food industry. http://www.standa-fr.com/eng/laboratoires-standa/sanico/. Last accessed: 04/02/2014.

Lawrie, K., Mills, A., \& Hazafy, D. (2013). Simple inkjet-printed, UV-activated oxygen indicator. Sensors and Actuators B: Chemical, 176, 1154-1159.

Lee, D. S. (2014). Antioxidant packaging system. In J. H. Han (Ed.), Innovations in food packaging (pp. 111-131). San Diego, USA: Academic Press.

Lee, K., \& Ko, S. (2014). Proof-of-concept study of a whey protein isolate based carbon dioxide indicator to measure the shelf-life of packaged foods. Food Science and Biotechnology, 23(1), 115-120.

Lee, K. T. (2010). Quality and safety aspects of meat products as affected by various physical manipulations of packaging materials. Meat Science, 86(1), 138-150.

Lee, S.-K., Mills, A., \& Leprea, A. (2004). An intelligence ink for oxygen. Chemical Communications, 1912-1913.

Lee, S. J., \& Rahman, A. T. M. M. (2014). Intelligent packaging for food products. In J. H. Han (Ed.), Innovations in food packaging (Second ed., pp. 171-209). San Diego, USA: Academic Press.

LINPAC. (2012). INPAC Packaging partners Addmaster to tackle packaging bugs. http://www.linpacpackaging.com/pt-pt/news/201208/linpac-packaging-partnersaddmaster-tackle-packaging-bugs. Last accessed: 21/03/202014.

LINPAC. (2013). Not just trays and film. http://www.linpacpackaging.com/en/not-just-traysand-film. Last accessed: 15/03/2014.

Liu, F., Dai, R., Zhu, J., \& Li, X. (2010). Optimizing color and lipid stability of beef patties with a mixture design incorporating with tea catechins, carnosine, and alpha-tocopherol. Journal of Food Engineering, 98(2), 170-177.

Llorens, A., Lloret, E., Picouet, P. A., Trbojevich, R., \& Fernandez, A. (2012). Metallic-based micro and nanocomposites in food contact materials and active food packaging. Trends in Food Science \& Technology, 24(1), 19-29.

Lloret, E., Picouet, P., \& Fernández, A. (2012). Matrix effects on the antimicrobial capacity of silver based nanocomposite absorbing materials. LWT - Food Science and Technology, 49(2), 333-338.

López-de-Dicastillo, C., Gómez-Estaca, J., Catalá, R., Gavara, R., \& Hernández-Muñoz, P. (2012). Active antioxidant packaging films: Development and effect on lipid stability of brined sardines. Food Chemistry, 131(4), 1376-1384.

Luchansky, J. B., Call, J. E., Hristova, B., Rumery, L., Yoder, L., \& Oser, A. (2005). Viability of Listeria monocytogenes on commercially-prepared hams surface treated with acidic calcium sulfate and lauric arginate and stored at $4{ }^{\circ} \mathrm{C}$. Meat Science, 71(1), 92-99.

Ma, H. J., Ledward, D. A., Zamri, A. I., Frazier, R. A., \& Zhou, G. H. (2007). Effects of high pressure/thermal treatment on lipid oxidation in beef and chicken muscle. Food Chemistry, 104(4), 1575-1579.

Manzanarez-López, F., Soto-Valdez, H., Auras, R., \& Peralta, E. (2011). Release of $\alpha$-tocopherol from poly(lactic acid) films, and its effect on the oxidative stability of soybean oil. Journal of Food Engineering, 104(4), 508-517.

Marcos, B., Aymerich, T., \& Garriga, M. (2005). Evaluation of high pressure processing as an additional hurdle to control Listeria monocytogenes and Salmonella enterica in low-acid fermented sausages. Journal of Food Science, 70(7), m339-m344.

Marcos, B., Aymerich, T., Garriga, M., \& Arnau, J. (2013). Active packaging containing nisin and high pressure processing as post-processing listericidal treatments for convenience fermented sausages. Food Control, 30(1), 325-330. 
Marcos, B., Aymerich, T., Monfort, J. M., \& Garriga, M. (2007). Use of antimicrobial biodegradable packaging to control Listeria monocytogenes during storage of cooked ham. International Journal of Food Microbiology, 120(1-2), 152-158.

Marcos, B., Aymerich, T., Monfort, J. M., \& Garriga, M. (2008). High-pressure processing and antimicrobial biodegradable packaging to control Listeria monocytogenes during storage of cooked ham. Food Microbiology, 25(1), 177-182.

Marcos, B., Aymerich, T., Monfort, J. M., \& Garriga, M. (2010). Physical Performance of Biodegradable Films Intended for Antimicrobial Food Packaging. Journal of Food Science, 75(8), E502-E507.

Marcos, B., Jofré, A., Aymerich, T., Monfort, J. M., \& Garriga, M. (2008). Combined effect of natural antimicrobials and high pressure processing to prevent Listeria monocytogenes growth after a cold chain break during storage of cooked ham. Food Control, 19(1), 76-81.

Market Research. (2014). Active \& Intelligent Packaging. http://www.marketresearch.com/Freedonia-Group-Inc-v1247/Active-Intelligent-Packaging7979079/. Last accessed: 11/03/2014.

Martínez-Olmos, A., Fernández-Salmerón, J., Lopez-Ruiz, N., Rivadeneyra Torres, A., CapitanVallvey, L. F., \& Palma, A. J. (2013). Screen Printed Flexible Radiofrequency Identification Tag for Oxygen Monitoring. Analytical Chemistry, 85(22), 11098-11105.

Maxwell Chase Technologies. (2014). Fresh-R-Pax ® trays. http://www.maxwellchase.com/food-packaging/absorbent-trays/. Last accessed: 14/02/2014.

Mc Carthy, T. L., Kerry, J. P., Kerry, J. F., Lynch, P. B., \& Buckley, D. J. (2001). Assessment of the antioxidant potential of natural food and plant extracts in fresh and previously frozen pork patties. Meat Science, 57(2), 177-184.

McArdle, R. A., Marcos, B., Kerry, J. P., \& Mullen, A. M. (2011). Influence of HPP conditions on selected beef quality attributes and their stability during chilled storage. Meat Science, 87(3), 274-281.

McArdle, R. A., Marcos, B., Mullen, A. M., \& Kerry, J. P. (2013). Influence of HPP conditions on selected lamb quality attributes and their stability during chilled storage. Innovative Food Science \& Emerging Technologies, 19, 66-72.

Millette, M., Le Tien, C., Smoragiewicz, W., \& Lacroix, M. (2007). Inhibition of Staphylococcus aureus on beef by nisin-containing modified alginate films and beads. Food Control, 18(7), 878-884.

Mills, A. (2005). Oxygen indicators and intelligent inks for packaging food. Chemical Society Reviews, 34, 1003-1011.

Mills, A., Doyle, G., Peiro, A. M., \& Durrant, J. (2006). Demonstration of a novel, flexible, photocatalytic oxygen-scavenging polymer film. Journal of Photochemistry and Photobiology a-Chemistry, 177(2-3), 328-331.

Mills, A., \& Hazafy, D. (2009). Nanocrystalline SnO2-based, UVB-activated, colourimetric oxygen indicator. Sensors and Actuators B: Chemical, 136(2), 344-349.

Mills, A., \& Lawrie, K. (2011). Novel photocatalyst-based colourimetric indicator for oxygen: Use of a platinum catalyst for controlling response times. Sensors and Actuators B: Chemical, 157(2), 600-605.

Mitsubishi-Kagaku Foods Corporation. (2002). Wasaouro ${ }^{\mathrm{TM}} \quad$ Products. $^{2}$ http://www.mfc.co.jp/wasaouro/e/products/. Last accessed: 05/02/2014.

Mitsubishi Gas Chemical. (2009a). AGELESS ${ }^{\circledR}$. $\quad$ http://www.mgca.com/AGELESS/AgelessFeatures.html. Last accessed: 21/03/2014.

$\begin{array}{llll}\text { Mitsubishi Gas (2009b). Chemical. OMAC . } & \text { http://www.mgc- }\end{array}$ a.com/AGELESS/OmacEffects.html. Last accessed: 20/01/2014.

Mitsubishi Gas Chemical. (2014). AGELESS EYE Oxygen Indicator. http://www.mgc.co.jp/eng/products/abc/ageless/eye.html. Last accessed: 15/03/2014 
Mitsumoto, M., O'Grad, M. N., Kerry, J. P., \& Buckley, D. J. (2005). Addition of tea catechins and vitamin $C$ on sensory evaluation, colour and lipid stability during chilled storage in cooked or raw beef and chicken patties. Meat Science, 69(4), 773-779.

Mondi. (2011). Nor ${ }^{\circledR}$ Absorbit makes your food nice and crispy http://www.mondigroup.com/desktopdefault.aspx/tabid-2179/2472 read-22564/. Last accessed: $12 / 03 / 22014$.

Mondi. (2014). Intelligent box. http://www.mondigroup.com/products/desktopdefault.aspx/tabid-1784/. Last accessed: 12/02/2014.

Mousavi, A., Sarhadi, M., Lenk, A., \& Fawcett, S. (2002). Tracking and traceability in the meat processing industry. British Food Journal, 104(1), 7-19.

Muriel-Galet, V., López-Carballo, G., Gavara, R., \& Hernández-Muñoz, P. (2012). Antimicrobial food packaging film based on the release of LAE from EVOH. International Journal of Food Microbiology, 157(2), 239-244.

Nadarajah, G., Han, J. H., \& Holley, R. A. (2005). Inactivation of Escherichia Coli O157:H7 in packaged ground beef by allyl isothiocyanate. International Journal of Food Microbiology, 99, 269-279.

Nanopack. (2014). NANOPACK technology \& packaging, S.L., http://www.nanopack.es/nanopack/. Last accessed: 21/03/2014.

Nerín, C., Tovar, L., Djenane, D., Camo, J., Salafranca, J., Beltrán, J. A., \& Roncalés, P. (2006). Stabilization of Beef Meat by a New Active Packaging Containing Natural Antioxidants. Journal of Agricultural and Food Chemistry, 54(20), 7840-7846.

Nguyen, V. T., Gidley, M. J., \& Dykes, G. A. (2008). Potential of a nisin-containing bacterial cellulose film to inhibit Listeria monocytogenes on processed meats. Food Microbiology, 25(3), 471-478

Nopwinyuwong, A., Trevanich, S., \& Suppakul, P. (2010). Development of a novel colorimetric indicator label for monitoring freshness of intermediate-moisture dessert spoilage. Talanta, 81(3), 1126-1132.

O'Grady, M. N., \& Kerry, J. P. (2008). Smart packaging technologies and their application in conventional meat packaging systems. In F. Toldrá (Ed.), Meat Biotechnology (pp. 425-451). New York, USA: Springer Science and Business Media.

Ojagh, S. M., Rezaei, M., Razavi, S. H., \& Hosseini, S. M. H. (2010). Effect of chitosan coatings enriched with cinnamon oil on the quality of refrigerated rainbow trout. Food Chemistry, 120(1), 193-198.

Oussalah, M., Caillet, S., Salmiéri, S., Saucier, L., \& Lacroix, M. (2004). Antimicrobial and Antioxidant Effects of Milk Protein-Based Film Containing Essential Oils for the Preservation of Whole Beef Muscle. Journal of Agricultural and Food Chemistry, 52(18), 5598-5605.

Oussalah, M., Caillet, S., Salmiéri, S., Saucier, L., \& Lacroix, M. (2006). Antimicrobial effects of alginate-based film containing essential oils for the preservation of whole beef muscle. Journal of Food Protection, 69(10), 2364-2369.

Ozdemir, M., \& Floros, J. D. (2004). Active food packaging technologies. Crit Rev Food Sci Nutr, 44(3), 185-193.

Pacquit, A., Frisby, J., Diamond, D., Lau, K. T., Farrell, A., Quilty, B., \& Diamond, D. (2007). Development of a smart packaging for the monitoring of fish spoilage. Food Chemistry, 102(2), 466-470.

Pacquit, A., Lau, K. T., McLaughlin, H., Frisby, J., Quilty, B., \& Diamond, D. (2006). Development of a volatile amine sensor for the monitoring of fish spoilage. Talanta, 69(2), 515-520.

Paper Pak Industries. (2014). The Natural Way to Extend Freshness. http://www.paperpakindustries.com/food/ultrazap xtendapak red meat.php. Last accessed: 04/03/2014. 
Park, H.-Y., Kim, S.-J., Kim, K. M., You, Y.-S., Kim, S. Y., \& Han, J. (2012). Development of Antioxidant Packaging Material by Applying Corn-Zein to LLDPE Film in Combination with Phenolic Compounds. Journal of Food Science, 77(10), E273-E279.

Park, H., Kim, Y., Jung, S., Kim, H., \& Lee, S. (2013). Response of microbial time temperature indicator to quality indices of chicken breast meat during storage. Food Science and Biotechnology, 22(4), 1145-1152.

Pereira de Abreu, D. A., Paseiro Losada, P., Maroto, J., \& Cruz, J. M. (2010). Evaluation of the effectiveness of a new active packaging film containing natural antioxidants (from barley husks) that retard lipid damage in frozen Atlantic salmon (Salmo salar L.). Food Research International, 43(5), 1277-1282.

Pereira de Abreu, D. A., Paseiro Losada, P., Maroto, J., \& Cruz, J. M. (2011). Natural antioxidant active packaging film and its effect on lipid damage in frozen blue shark (Prionace glauca). Innovative Food Science \& Emerging Technologies, 12(1), 50-55.

Pérez-Juan, M., Kondjoyan, A., Picouet, P., \& Realini, C. E. (2012). Effect of marination and microwave heating on the quality of Semimembranosus and Semitendinosus muscles from Friesian mature cows. Meat Science, 92(2), 107-114.

Perry, M. R., \& Lentz, R. R. (2009). Susceptors in microwave packaging. In M. W. Lorence \& P. S. Pesheck (Eds.), Development of packaging and products for use in microwave ovens (pp. 207-236). Cambridge, UK: Woodhead Publishing Limited.

Picouet, P. A., Fernandez, A., Realini, C. E., \& Lloret, E. (2014). Influence of PA6 nanocomposite films on the stability of vacuum-aged beef loins during storage in modified atmospheres. Meat Science, 96(1), 574-580.

Piringer, O. (2000). Transport equations and their solutions. In O. Piringer, Baner, A.L. (Ed.), Plastic packaging materials for foods (pp. 183-219). Weinhem, Germany: Wiley-VCN.

Pospiskova, K., Safarik, I., Sebela, M., \& Kuncova, G. (2012). Magnetic particles-based biosensor for biogenic amines using an optical oxygen sensor as a transducer. Microchimica ActaAn International Journal on Analytical Micro- and Nanochemistry, 311-318.

Ray, B. (1992). Bacteriocins of starter culture bacteria as food biopreservatives. In B. Ray \& M. Daeschel (Eds.), Food biopreservatives of microbial origin (pp. 178-201). Boca Raton, Fla.: CRC Press Inc.

Realini, C. E., Guardia, M. D., Garriga, M., Perez-Juan, M., \& Arnau, J. (2011). High pressure and freezing temperature effect on quality and microbial inactivation of cured pork carpaccio. Meat Science, 88(3), 542-547.

Regier, M. (2014). Microwavable food packaging. In J. H. Han (Ed.), Innovations in food packaging (pp. 495-514). San Diego, USA: Academic Press.

Riehle, L. S., \& Versteylen, S. (2010). Absorbent pads for food packaging (EP 2265136 A1). In: Google Patents. https://www.google.nl/patents/EP2265136A1?cl=en. Last accessed: 07/12/2013.

Ritschkoff, A.-C., Smolander, M., \& Paajanen, M. (2007). Development of Nanotechnologies and Nanomaterials. In Russian-Finnish Conference. Helsinki, Finland.

Roberts, L., Lines, R., Reddy, S., \& Hay, J. (2011). Investigation of polyviologens as oxygen indicators in food packaging. Sensors and Actuators B: Chemical, 152(1), 63-67.

Rodriguez-Aguilera, R., \& Oliveira, J. C. (2009). Review of Design Engineering Methods and Applications of Active and Modified Atmosphere Packaging Systems. Food Engineering Reviews, 1(1), 66-83.

Ryynanen, S., Risman, P. O., \& Ohlsson, T. (2004). Hamburger composition and microwave heating uniformity. Journal of Food Science, 69(7), M187-M196.

Sacchetti, G., Maietti, S., Muzzoli, M., Scaglianti, M., Manfredini, S., Radice, M., \& Bruni, R. (2005). Comparative evaluation of 11 essential oils of different origin as functional antioxidants, antiradicals and antimicrobials in foods. Food Chemistry, 91(4), 621-632. 
Salinas, Y., Ros-Lis, J. V., Vivancos, J.-L., Martínez-Máñez, R., Marcos, M. D., Aucejo, S., Herranz, N., Lorente, I., \& Garcia, E. (2014). A novel colorimetric sensor array for monitoring fresh pork sausages spoilage. Food Control, 35(1), 166-176.

Scaffaro, R., Botta, L., Marineo, S., \& Puglia, A. M. (2011). Incorporation of Nisin in Poly (Ethylene-Co-Vinyl Acetate) Films by Melt Processing: A Study on the Antimicrobial Properties. Journal of Food Protection, 74(7), 1137-1143.

Sealed Air. (2013). Cryovac ${ }^{\circledR}$ OS Films - Rapid Headspace. http://www.cryovac.com/NA/EN/pdf/osfilms.pdf. Last accessed: 10/03/2014.

SEALPAC. (2014a). MicVac. Steam cooking with an innovative label. http://www.sealpac.de/index.php?id=176\&L=171. Last accessed: 03/04/2014.

SEALPAC. (2014b). TenderPac. Best meat quality, appetizing appearance. http://www.sealpac.de/index.php?id=173\&L=171. Last accessed: 15/02/2014.

Sen, L., Hyun, K.-H., Kim, J.-W., Shin, J.-W., \& Eom, K.-H. (2013). The Design of Smart RFID System with Gas Sensor for Meat Freshness Monitoring Advanced Science and Technology Letters, 41, 17-20.

Sirane. (2011). A-Crisp ${ }^{\mathrm{TM}}$ boxes, boards, sleeves and liners for crisping in a microwave. http://www.sirane.com/food-packaging-products/microwave-susceptors-crisp-itrange/sira-cook-crisp-it-boards.html. Last accessed: 10/03/2014.

Siripatrawan, U., \& Harte, B. R. (2010). Physical properties and antioxidant activity of an active film from chitosan incorporated with green tea extract. Food Hydrocolloids, 24(8), 770-775.

Sirocchi, V., Caprioli, G., Cecchini, C., Coman, M. M., Cresci, A., Maggi, F., Papa, F., Ricciutelli, M., Vittori, S., \& Sagratini, G. (2013). Biogenic amines as freshness index of meat wrapped in a new active packaging system formulated with essential oils of Rosmarinus officinalis. International journal of Food Sciences and Nutrition, 64(8), 921-928.

Skjervold, P. O., Salbu, B., Heyerdahl, P. H., \& Lien, H. (2007). Full history time-temperature indicator system. In: Google Patents.

Smits, E., Schram, J., Nagelkerke, M., Kusters, R., Heck, G. v., Acht, V. v., Koetse, M., Brand, J. v. d., Gelinck, G., \& Schoo, H. (2012). Development of printed RFID sensor tags for smart food packaging. In 14th International Meeting on Chemical Sensors (pp. 403-406). Nuremberg, Germany.

Smolander, M. (2008). Freshness indicators for food packaging. In J. F. Kerry \& F. Butler (Eds.), Smart packaging technologies for fast moving consumer goods (pp. 111-128). West Sussex, England: John Wiley and Sons Ltd.

Song, N.-B., Lee, J.-H., Al Mijan, M., \& Song, K. B. (2014). Development of a chicken feather protein film containing clove oil and its application in smoked salmon packaging. $L W T$ Food Science and Technology, 57(2), 453-460.

Sorbent Systems. (2014). Oxygen Indicators Tablets (Tell-Tab). http://www.sorbentsystems.com/tell-tab.html. Last accessed: 15/03/2014

Souza, C. O., Silva, L. T., Silva, J. R., López, J. A., Veiga-Santos, P., \& Druzian, J. I. (2011). Mango and Acerola Pulps as Antioxidant Additives in Cassava Starch Bio-based Film. Journal of Agricultural and Food Chemistry, 59(6), 2248-2254.

Speer, D. V., Edwards, F. B., Beckwith, S. W., Rivett, J., \& Kennedy, T. D. (2009). Method of triggering a film containing an oxygen scavenger (US 7504045 B2). In: Google Patents. http://www.google.com.tr/patents/US7504045.

Sperber, W. H. (2010). Introduction to the microbial spoilage of foods and beverages. In W. H. Sperber \& M. P. Doyle (Eds.), Compendium of the microbial spoilage of foods and beverages (pp. 1-40). N.Y.: Springer.

Sun, X. D., \& Holley, R. A. (2012). Antimicrobial and antioxidative strategies to reduce pathogens and extend the shelf life of fresh red meats. Comprehensive Reviews in Food Science and Food Safety, 11(4), 340-354. 
Sung, S.-Y., Sin, L. T., Tee, T.-T., Bee, S.-T., Rahmat, A. R., \& Rahman, W. A. W. A. (2014). Control of bacteria growth on ready-to-eat beef loaves by antimicrobial plastic packaging incorporated with garlic oil. Food Control, 39(0), 214-221.

Suppakul, P., Miltz, J., Sonneveld, K., \& Bigger, S. W. (2003). Active packaging technologies with emphasis on antimicrobial packaging and its applications. Journal of Food Science, 68(2), 408-420.

Swedberg, C. (2011). Norwegian Group Tracks Super-Chilled Meat. RFID Journal, http://www.rfidjournal.com/articles/view?9022. Last accessed: 06/03/2014.

Swedberg, C. (2012). Bereket Doner Tracks Its Meat Products Via RFID. RFID Journal, http://www.rfidjournal.com/articles/view?10246. Last accessed: 06/03/12014.

Tagg, J. R., Dajani, A. S., \& Wannamaker, L. W. (1976). Bacteriocins of Gram-positive bacteria. Bacteriological Reviews, 40, 722-756.

Tempix. (2014). The Tempix temperature indicator. http://tempix.com/. Last accessed: 02/03/2014.

Temptime Corp. (2014). Reading Fresh-Check ${ }^{\circledR}$ Time Temperature Indicators. http://www.fresh-check.com/reading.asp. Last accessed: 02/03/2014.

Tian, F., Decker, E. A., \& Goddard, J. M. (2013). Controlling lipid oxidation of food by active packaging technologies. Food \& Function, 4(5), 669-680.

Timestrip. (2012). Timestrip ${ }^{\circledR} \quad$ Cold Chain Products for Food http://www.timestrip.com/coldchain food.php. Last accessed: 15/03/2014.

Torrieri, E., Carlino, P. A., Cavella, S., Fogliano, V., Attianese, I., Buonocore, G. G., \& Masi, P. (2011). Effect of modified atmosphere and active packaging on the shelf-life of fresh bluefin tuna fillets. Journal of Food Engineering, 105(3), 429-435.

Traceo. (2014). Applications. $\quad$ http://www.traceo.com/en/food/foodindustry/applications.html. Last accessed: 02/03/2014.

Trinetta, V., Floros, J. D., \& Cutter, C. N. (2010). Sakacin A-containing pullulan film: an active packaging system to control epidemic clones of Listeria monocytogenes in ready-to-eat foods. Journal of Food Safety, 30(2), 366-381.

Umuhumuza, L., \& Sun, X. (2011). Rapid detection of pork meat freshness by using L-cysteinemodified gold electrode. European Food Research and Technology, 232(3), 425-431.

Ünalan, I. U., Korel, F., \& Yemenicioglu, A. (2011). Active packaging of ground beef patties by edible zein films incorporated with partially purified lysozyme and $\mathrm{Na}_{2}$ EDTA. International Journal of Food Science and Technology, 46(6), 1289-1295.

UPM. (2007). UPM Shelf Life Guard keeping an eye on packaged foods. http://www.upm.com/EN/MEDIA/All-news/Pages/UPM-Shelf-Life-Guard-Keeping-an-Eyeon-Packaged-Foods-001-to-010-helmi-2011-2019-2014.aspx. Last accessed: 07/03/2014.

VacPac. (2014). SmartPouch ${ }^{\oplus}$ Susceptor technology for superior cooking. http://www.vacpacinc.com/smartpouch.html. Last accessed: 15/02/2014.

Vaikousi, H., Biliaderis, C. G., \& Koutsoumanis, K. (2008). Development of a microbial time/temperatureindicator prototype for monitoring the microbiological quality of chilled foods. Applied and Environmental Microbiology, 74, 3242-3250.

Vaikousi, H., Biliaderis, C. G., \& Koutsoumanis, K. P. (2009). Applicability of a microbial Time Temperature Indicator (TTI) for monitoring spoilage of modified atmosphere packed minced meat. International Journal of Food Microbiology, 133(3), 272-278.

Varcode. (2014). FreshCode ${ }^{\mathrm{TM}}$ label. http://www.varcode.com/?CategorylD=158\&ArticlelD=178. Last accessed: 02/03/2014.

Vartdal Plastindustri. (2009). Første CO2-emitter for norsk matindustri. http://vartdalplast.no/bibliotek/Superfresh eng LR-1.pdf. Last accessed: 14/03/2014.

Vermeiren, L., Devlieghere, F., \& Debevere, J. (2002). Effectiveness of some recent antimicrobial packaging concepts. Food Additives and Contaminants, 19(Supplement), 163171. 
Vermeiren, L., Devlieghere, F., van Beest, M., de Kruijf, N., \& Debevere, J. (1999). Developments in the active packaging of foods. Trends in Food Science \& Technology, 10(3), 77-86.

Vermeiren, L., Heirlings, L., Devlieghere, F., \& Debevere, J. (2003). Oxygen, ethylene and other scavengers. In R. Ahvenainen (Ed.), Novel food packaging techniques (Vol. Cambridge, UK): Woodhead Publishing Ltd.

Vignolo, G., Palacios, J., Farías, M. E., Sesma, F., Schillinger, U., Holzapfel, W., \& Olliver, W. (2000). Combined effect of bacteriocins on the survival of various Listeria species in broth and meat. Current Microbiology, 41(6), 410-416.

VITSAB. (2013). Seafood TTI labels. http://vitsab.com/?page id=1983. Last accessed 02/03/2014.

Vu, C. H. T., \& Won, K. (2013). Novel water-resistant UV-activated oxygen indicator for intelligent food packaging. Food Chemistry, 140(1-2), 52-56.

Wasserman, E. (2010). Canadian Beef Processor Deploys RFID for Food Safety. RFID Journal, https://www.rfidjournal.com/purchase-

access?type=Article\&id=7331\&r=\%7332Farticles\%7332Fview\%7333F7331\%7332F7206/730 3/2014. Last accessed: 06/03/2014.

Williams, J., Myers, K., Owens, M., \& Bonne, M. (2006). Food quality indicator. In: Google Patents.

Xiao-e, L., Green, A. N. M., Haque, S. A., Mills, A., \& Durtant, J. R. (2004). Light-driven oxygen scavenging by titania/polymer nanocomposite films. Journal of Photochemistry and Photobiology a-Chemistry, 162(2-3), 253-259.

Yam, K. L., Takhistov, P. T., \& Miltz, J. (2005). Intelligent Packaging: Concepts and Applications. Journal of Food Science, 70(1), R1-R10.

Yingyuad, S., Ruamsin, S., Reekprkhon, D., Douglas, S., Pongamphai, S., \& Siripatrawan, U. (2006). Effect of chitosan coating and vacuum packaging on the quality of refrigerated grilled pork. Packaging Technology and Science, 19(3), 149-157.

Yoshida, C. M. P., Maciel, V. B. V., Mendonça, M. E. D., \& Franco, T. T. (2014). Chitosan biobased and intelligent films: Monitoring $\mathrm{pH}$ variations. LWT - Food Science and Technology, 55(1), 83-89.

Table 1. Types of active packaging and commercial applications applied to muscle foods.

\begin{tabular}{|c|c|c|}
\hline \multicolumn{3}{|l|}{ ACTIVE PACKAGING } \\
\hline Commercial Name & Supplier & System \\
\hline \multicolumn{3}{|l|}{ Moisture Absorbers } \\
\hline Dri-Loc $^{\circledR}$ & Sealed Air Corporation & Absorbent pad \\
\hline MoistCatch & Kyodo Printing Co., Ltd. & Absorbent pad \\
\hline MeatGuard & McAirlaid Inc. & Absorbent pad \\
\hline Linpac & Linpac Packaging Ltd. & Absorbent tray \\
\hline Fresh-R-Pax ${ }^{\oplus}$ & Maxwell Chase Technologies & Absorbent tray \\
\hline TenderPac ${ }^{\oplus}$ & SEALPAC & Dual-compartment system \\
\hline Nor Absorbit & Nordenia International AG & Microwavable film \\
\hline \multicolumn{3}{|c|}{ Antimicrobial Packaging } \\
\hline Biomaster & Addmaster Limited & Silver-based masterbatch \\
\hline Aglon ${ }^{\oplus}$ & Life Materials Technology Limited & Silver-based masterbatch \\
\hline Irgaguard & BASF & Silver-based masterbatch \\
\hline Surfacine & $\begin{array}{l}\text { Surfacine Development Company } \\
\text { LLC }\end{array}$ & Silver-based masterbatch \\
\hline IonPure & Solid Spot LLC & Silver-based masterbatch \\
\hline $\mathrm{d}_{2} \mathrm{p}^{\oplus}$ & Symphony Environmental Ltd & Silver-based masterbatch \\
\hline Bactiblock & NanoBioMatters & Silver-based masterbatch \\
\hline
\end{tabular}


Biomaster ${ }^{\circledast}$

Food-touch $^{\oplus}$

Sanic Films

SANICO ${ }^{\circ}$

Wasaouro $^{\mathrm{TM}}$

\section{Carbon dioxide emitters}

$\mathrm{CO}_{2}{ }^{\oplus}$ Fresh Pads
UltraZap ${ }^{\oplus}$ Xtenda Pak
pads
SUPERFRESH

Oxygen scavengers

OxyGuard $^{\mathrm{TM}}$

OxyCatch $^{\text {TM }}$

FreshPax

$\mathrm{ATCO}^{\circ}$

Ageless ${ }^{\circledR}$

Cryovac ${ }^{\circledR}$ OS2000

Enzyme-based

Shelfplus ${ }^{\oplus} \mathrm{O}_{2}$

OxyRx ${ }^{\text {TM }}$

OMAC ${ }^{\oplus}$

\section{Antioxidant}

ATOX

Other

FreshCase

Sira-Crisp ${ }^{\mathrm{TM}}$
SmartPouch $^{\oplus}$
Flexis $^{\mathrm{TM}}$
MicVac $^{\oplus}$

Sira-Crisp ${ }^{\mathrm{Tm}}$

Flexis $^{\mathrm{TM}}$

MicVac
Linpac Packaging Ltd.

Microbeguard Corp.

Nanopack

Laboratories STANDA

Mitsubishi-Kagaku Foods Corp.

$\mathrm{CO}_{2}$ Technologies

Paper Pak Industries

Vartdal Plastindustri AS

Clariant Ltd.

Kyodo Printing Company, Ltd.

Multisorb Technolgoies, Inc.

Laboratories STANDA

Mitsubishi Gas Chemical Inc.

Sealed Air Corporation, USA

Bioka Ltd.

Albis Plastic $\mathrm{GmbH}$

Mullinix Packages Inc.

Mitsubishi Gas Chemical Inc.

Artibal SA

Bemis Company Inc.

Sirane Ltd.

VacPac Inc.

Avery Dennison Corp.

SEALPAC GmbH
Silver-based trays and films Interleavers

Interleavers

Antifungal coating

Antibacterial and antifungal sheets, labels and films

$\mathrm{CO}_{2}$ emitter pad

$\mathrm{CO}_{2}$ emitter and antimicrobial pad

Box system with $\mathrm{CO}_{2}$ emitter

Sachet

Sachet

Sachet

Label

Label

Film

Film

Masterbatch

Container suitable for high

temperature

Film suitable for high

temperature

Film coating

Sodium nitrite containing film that allows red colour formation in vaccum packed meat

Microwave susceptor

Microwave susceptor

Steam valve

Steam valve 
Table 2. Types of intelligent packaging and commercial applications applied to muscle foods.

\begin{tabular}{|c|c|c|}
\hline $\begin{array}{c}\text { INTELLIGENT PACKAGING } \\
\text { Commercial Name }\end{array}$ & Supplier & System \\
\hline \multicolumn{3}{|c|}{ Time temperature indicators (TTI) } \\
\hline $3 \mathrm{M}$ Monitor Mark & 3M Company & Fatty acid ester TTI \\
\hline Keep-it ${ }^{\oplus}$ & Keep-it Technologies & Chemical TTI \\
\hline Fresh-Check & Temptime Corp. & Polymerization reaction TTI \\
\hline VITSAB ${ }^{\circ}$ & VITSAB International $A B$ & Enzymatic TTI \\
\hline $\mathrm{OnVu} \mathrm{u}^{\mathrm{TM}}$ & Freshpoint and Ciba & Photochemical reaction TTI \\
\hline TopCryo $^{\mathrm{TM}}$ & TRACEO & Microbiological TTI \\
\hline FreshCode $^{\mathrm{TM}}$ & Varcode Ltd. & Barcode based label TTI \\
\hline Tempix & Tempix AB & Barcode based label TTI \\
\hline \multicolumn{3}{|l|}{ Integrity indicators } \\
\hline Timestrip ${ }^{\circ}$ & Timestrip Ltd. & Time indicator label \\
\hline Novas ${ }^{\circ}$ & Insignia Technologies Ltd. & Time indicator label \\
\hline Best-by ${ }^{\top M}$ & FreshPoint Lab. & Time indicator label \\
\hline Ageless Eye ${ }^{\bullet}$ & Mitsubishi Gas Chemical Inc. & Gas indicator tablet \\
\hline Tell-Tab & IMPAK & Gas indicator tablet \\
\hline $\mathrm{O}_{2} \mathrm{Sense}^{\mathrm{TM}}$ & Freshpoint Lab. & Gas indicator tablet \\
\hline \multicolumn{3}{|c|}{ Freshness indicators and sensors } \\
\hline Fresh Tag ${ }^{\circ}$ & COX Technologies & Colorimetric indicator \\
\hline SensorQ ${ }^{\mathrm{TM}}$ & $\begin{array}{l}\text { DSM NV and Food Quality } \\
\text { Sensor International Inc. }\end{array}$ & $\mathrm{pH}$-sensing indicator \\
\hline Raflatac & VTT and UPM Raflatac & $\begin{array}{l}\text { Colorimetric indicator (silver } \\
\text { nanolayers) }\end{array}$ \\
\hline $\begin{array}{l}\text { Food Sentinel } \\
\text { System }\end{array}$ & SIRA Technologies Inc. & Biosensor (barcode) \\
\hline Toxin Guard ${ }^{\mathrm{TM}}$ & Toxin Alert Inc. & Biosensor (film) \\
\hline \multicolumn{3}{|c|}{ Radiofrequency identification tags (RFID) } \\
\hline Easy2 $2 \log ^{\mathbb{Q}}$ & CAEN RFID Srl & TT sensor tag \\
\hline CS8304 & Convergence Systems Ltd. & TT sensor tag \\
\hline TempTRIP & TempTRIP LLC & TT sensor tag \\
\hline Intelligent box & Mondi Plc & $\begin{array}{l}\text { Box with integrated TT sensor } \\
\text { tag }\end{array}$ \\
\hline Intelligent fish box & Craemer Group GmbH & $\begin{array}{l}\text { Box with integrated TT sensor } \\
\text { tag }\end{array}$ \\
\hline
\end{tabular}

